\title{
Changing landscapes, livelihoods and village welfare in the context of oil palm development
}

Authors:

Truly Santika ${ }^{1,2,3,4} *$, Kerrie A. Wilson ${ }^{1,2,5}$, Erik Meijaard ${ }^{2,3}$, Sugeng Budiharta ${ }^{2,6}$, Elizabeth A. Law ${ }^{1,2,7}$, Meindra Sabri ${ }^{8}$, Matthew Struebig ${ }^{4}$, Marc Ancrenaz ${ }^{3,9}$ \& Tun-Min Poh ${ }^{3}$

Author affiliations

1 The University of Queensland, School of Biological Sciences, Brisbane, QLD, Australia

2 ARC Centre of Excellence for Environmental Decisions, The University of Queensland, Brisbane, QLD, Australia

3 Borneo Futures, Brunei Darussalam

4 Durrell Institute of Conservation and Ecology (DICE), University of Kent, Canterbury CT2 7NR, United Kingdom

5 Institute for Future Environments, Queensland University of Technology, Brisbane, Australia

6 Purwodadi Botanic Garden-Indonesian Institute of Sciences, Jl. Surabaya-Malang Km. 65, Pasuruan, Jawa Timur, Indonesia

7 Norwegian Institute for Nature Research (NINA), Trondheim, Norway

8 Statistics Indonesia (BPS), JI. Dr. Sutomo 6-8, Jakarta 10710, Indonesia

9 Kinabatangan Orang-utan Conservation Programme, Sandakan, Sabah, Malaysia

\section{* Corresponding author:}

Truly Santika

Address: The University of Queensland, School of Biological Sciences, Brisbane, QLD, Australia Email: trulysantika@gmail.com

\section{Acknowledgements}

This study is part of the "Borneo Futures" initiative, and was supported by the Woodspring Trust, the Australian Research Council Centre of Excellence for Environmental Decisions and Future Fellowship programs, and the Arcus Foundation. 


\section{Changing landscapes, livelihoods and village welfare in the context of oil palm development}

\section{Abstract}

The United Nations' Sustainable Development Goals underscore the need for improved understanding of relationships between changes in landscapes, livelihoods, and social welfare, and how these relate to tackling poverty, inequality, and environmental degradation. Such assessments are especially relevant in the context of oil palm agricultural expansion, which has rapidly replaced traditional livelihoods and generates ongoing political debates around the world. Proponents of the oil palm industry have used economic objectives to justify expansion, while opponents have raised the negative socioecological impacts on communities. To assist the debate, we assessed the association between the change in landuses and climate, the change in village primary livelihoods towards monocultural oil palm cultivation, and the change in village welfare after adopting oil palm across Kalimantan, Indonesian Borneo, between 2000 and 2014. We show that the change in village primary livelihoods towards monocultural oil palm cultivation during this period was associated with complex interrelations between the expansion of agricultural industries, and conducive climate and market conditions for supporting agricultural production. The shift to oil palm monoculture brought significant economic benefit to villages, but this was limited to those with past exposure to plantation management and the market economy, such as in polyculture plantation villages. For villages where the majority of communities practiced traditional subsistence-based livelihoods (farming, foraging and fishing), the economic benefit from a shift to oil palm lasted only a few years after transition, while the socioecological welfare deteriorated. Furthermore, the shift to oil palm monoculture jeopardized food security among these subsistence livelihood villages. Baseline economic and socioecological conditions of villages, therefore, critically determine the success of the oil palm sector in providing economic benefits over the long term. Our study urgently calls for considering oil palm development objectives not only in terms of regional economic gain, but also the future maintenance of socioecological welfare of village communities.

Keywords: agriculture; Borneo; impact evaluation; Kalimantan; poverty; rural livelihoods; UN Sustainable Development Goals. 


\section{Introduction}

In many developing countries, over half the population live in rural areas, where poverty rates are high and livelihoods dependent on agriculture (FAO 2015). The bold vision of the United Nations via its Sustainable Development Goals (SDGs) is to eradicate poverty, combat inequality, and create or sustain economic growth and livelihoods, while preserving the planet, and mitigating the effects of climate change. The SDG framework underscores the need for better understanding of the nexus between the change in landscapes (land use and climate), livelihoods, and social welfare, through an integrated landscape approach to guide policy and planning programs in rural areas (Reed et al. 2016; Erbaugh \& Agrawal 2017). The framework also requires the evaluation of welfare through economic, social and ecological perspectives (Reed et al. 2017).

Subsistence farming and foraging (including hunting and gathering of forest products and fishing) are common traditional livelihood activities of rural communities across the developing world (Mertz et al. 2005; Padoch \& Pinedo-Vasquez 2010). In the 1960s, the Green Revolution brought highyielding crops and modernized cultivation systems across Asia, Africa and South America, which began a transition from traditional rural livelihoods to market-oriented crops, such as rubber, oil palm, coffee and other commodities, as well as industrial plantation methods (Ekadinata \& Vincent 2012; Van Vliet et al. 2013; Robinson 2018). Rubber, concentrated in Malaysia, Indonesia, Thailand, Sri Lanka and India, now accounts for a substantial volume of the world's exports (FAO 2015). Also in the South-East Asian region, oil palm production has rapidly increased with Malaysia and Indonesia now contributing more than $80 \%$ of world production of oil palm (FAO 2015). The plantation sector is dominated by large-scale plantation estates while smallholder farmers operating as part of nucleus estates or independently (Gatto et al. 2015), generating complex small and large-holder interactions.

Oil palm is currently one of the economic pillars of Indonesia and Malaysia, contributing substantially to foreign exchange earnings and providing employment for a large number of people (Koh \& Wilcove 2007; Meijaard et al. 2018). Continued viability of this crop is central for sustaining the economies of these producer countries. Driven by increased global populations and demands for food, fibre, and fuel, the extent of this crop has rapidly expanded over the last decades (Santika et al. 2015; Gaveau et al. 2016b). In Indonesia, this expansion has prompted ongoing debates among government ministries, with arguments for or against oil palm mainly being based on sectoral and institutional interests (Obidzinski et al. 2012). Poverty eradication and improvement in economic welfare is used by the proponents of oil palm industry to justify expansion, especially in remote forested landscapes where the poorest communities live (Buys 2007; Susanti \& Maryudi 2016). On the other hand, opponents of oil palm have raised concerns about the social and environmental impacts of the industry on rural welfare (Sayer et al. 2012; Sloan et al. 2019). Several small-scale studies indicate that benefits of oil palm agriculture to rural communities typically vary amongst individuals, with those possessing more land and capital (i.e. the least poor) benefiting the most (Obidzinski et al. 2014; Euler et al. 2017; Krishna et al. 2017). Such benefits likely also vary according to exposure to market economy (Scoones 2009). However, landscape-level analyses are yet to be undertaken to assess the impact of this crop more broadly.

Here we assessed the association between the change in landscapes (land uses and climate), the change in village primary livelihoods towards monocultural oil palm cultivation, and the change in village welfare after adopting oil palm monoculture across Kalimantan, Indonesian Borneo between 2000 and 2014. Oil palm monoculture villages are defined as villages where plantations were reported as the primary livelihood of the majority of village households according to the village-based census PODES (Potensi Desa or Village Potential) conducted by the Indonesian Bureau of Statistics (BPS Indonesia 2017), and where extensive land areas within the village boundaries are planted with oil palm and overlap with oil palm concessions. We focussed on three types of village primary livelihood sectors that existed prior to shifting to oil palm monoculture: (a) subsistence livelihood, (b) freshwater fishing, and (c) polyculture plantations. 
As the framework of analysis, we adapted the Sustainable Livelihood Approach (Scoones 1998; Bebbington 1999), which highlights the different elements that fundamentally shape rural livelihoods, which include: (1) access to different types of capital, assets, or welfare; (2) choice to pursue or adopt particular livelihood activities conditioned by resource endowments, biophysical circumstances, and exogenous factors; and (3) the resulting outcomes from adopting the new livelihood strategy that in turn affects or alters the capital or welfare (Scoones 1998). More specifically, our study aimed to answer three broad questions associated with each of the elements of the sustainable livelihood framework. First, what are the merits of villages having different livelihood systems in Kalimantan in terms of economic and socioecological welfare? Second, how do biophysical circumstances affect the change in village primary livelihood towards monocultural oil palm cultivation? Third, what is the impact of shifting the primary livelihood sector towards monocultural oil palm cultivation on village welfare, economically and socioecologically, and how does the impact vary across villages having different livelihood systems prior to oil palm developments?

\section{Materials and methods}

This section provides detailed methodologies of our study and is organized as follows. The first subsection presents an overview of the study area and village primary livelihoods in Kalimantan. The second subsection describes the primary data used in this study, which includes (1) indicators of village welfare and (2) proxies for village biophysical conditions. The third subsection describes the analysis approaches associated with each of the three research questions that we aimed to answer.

\subsection{Study area and village primary livelihoods}

Kalimantan $\left(530,000 \mathrm{~km}^{2}\right)$, the Indonesian part of the island of Borneo, comprised five provinces and 7,166 villages in 2014 (BPS Indonesia 2017). The island of Borneo has undergone rapid landscape transformation over the past decades, causing significant loss of natural forest and biodiversity (Gaveau et al. 2016b; Santika et al. 2017a), and impacting rural communities, particularly those who used to depend highly on forest and natural resource (Mukherjee \& Sovacool 2014). The island is characterised by changing rainfall patterns (Kumagai et al. 2013; Struebig et al. 2015; Sloan et al. 2017; McAlpine et al. 2018) with drought becoming more frequent and intense, which has exacerbated the occurrence and magnitude of wildfire and haze, affecting the health of millions of people (Othman et al. 2014; Koplitz et al. 2015) as well as oil palm productivity (MPOC 2013; Paterson \& Lima 2018).

Based on socioeconomic census data PODES collected roughly every 3 years at village level (BPS Indonesia 2017), spatiotemporal boundaries of oil palm concessions (Santika et al. 2015; Carlson et al. 2018), and the extent of (planted) oil palm plantations every five years between 2000 and 2015 (Gaveau et al. 2016a), five major village primary livelihoods were identified between 2000 and 2014 . These include: (1) subsistence livelihood, (2) freshwater fishing, (3) polyculture plantation, (4) oil palm monoculture, and (5) other sectors, which include wet rice farming, forestry (logging and tree plantation), horticulture, aquaculture, coastal fisheries, livestock, and non-agricultural activities. Although the Indonesian government has put tremendous efforts into increasing farmer attention to staple agriculture by establishing 'rice estates' in various parts of Kalimantan, only $5 \%$ of villages consider wet rice farming as their primary livelihood sector (BPS Indonesia 2017). We have therefore included wet rice farming under livelihood category 'other sector'. These livelihood categories represent the primary sectors upon which the majority of communities within a village depend for income (monetary and non-monetary), and the key sectors that mainly drive the village economy (BPS Indonesia 2017). The distribution of these livelihood systems across Kalimantan in 2011 and the change in the distribution every 3-5 years between 2000 and 2014 is shown in Fig. 1A-B. 

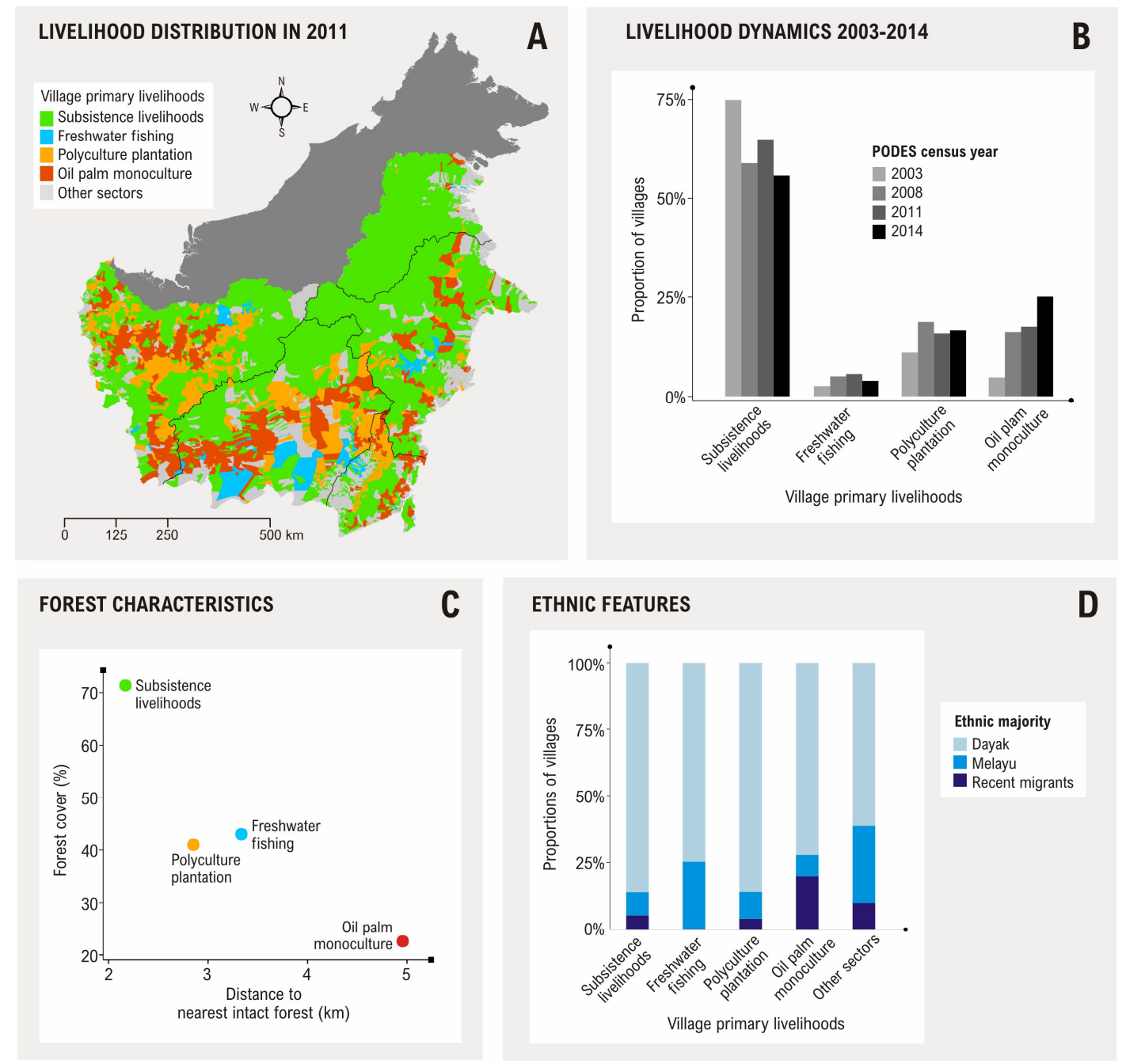

Fig. 1. (A) Distribution of different livelihood systems across villages in Kalimantan in 2011. Village primary livelihoods include: (1) subsistence livelihoods, (2) freshwater fishing, (3) polyculture plantation, (4) oil palm monoculture, and (5) other livelihood sectors. Black lines in the map represent provincial boundaries. (B) Change in the proportion of villages engaged in each livelihood sector between 2003 and 2014, showing marked increase in oil palm monoculture villages and sharp decline in subsistence livelihood villages. (C) Forest characteristics, (i.e. mean proportion of forest cover and forest connectivity measured as the mean distance to nearest intact forest patch), and (D) majority of ethnic groups: Dayak, Melayu, and recent migrants, in villages with different livelihood systems in Kalimantan.

Subsistence livelihoods in Kalimantan are supported by swidden rice agriculture on dryland, and typically supplemented by forest product collection in complex agroforestry landscapes (e.g.

tiwmawakng in West Kalimantan; simpukng in East Kalimantan; kaleka in Central Kalimantan) (Rahu et al. 2014; Budiharta et al. 2016). This livelihood category encompasses villages where food staple agriculture (padi or palawija) was reported as the predominant livelihood of the majority of communities and where the village land allocated to swidden is reported to be predominant compared to those allocated to wet rice farming (sawah) in the PODES data. Livelihood category freshwater fishing encompasses inland villages where fishing (perikanan tangkap) was reported as the primary sector in the PODES data. Freshwater fishing is a livelihood typical for villages located on the floodplains of large Kalimantan rivers and wetlands, such as the Mahakam, Barito, Kahayan, Kapuas, and Seruyan Rivers (Nooteboom \& de Jong Edwin 2010). Many inland fishing communities in Kalimantan are part-timers; 
these communities engage more in fishing during rainy seasons (or the wet years) and grow marketoriented crops on their land or are involved in timber harvesting once the river or wetland dries out (or during the dry years) (Neiland 2008). The dynamics of inland fishing is reflected by the higher number of villages reporting this livelihood category in the PODES censuses following a wet year (i.e. a year when rainfall during the dry months is higher than average) (Fig. S1). Livelihood category polyculture plantation encompasses villages where plantation (perkebunan) was reported as the primary livelihood of the majority of villagers in the PODES data and village land area does not overlap with any industrial oil palm concessions. Polyculture plantation outside concessions mainly includes independent smallholders of rubber, oil palm, coffee, and/or coconut under simple agroforestry system (Budiharta et al. 2016). Livelihood category oil palm monoculture encompasses villages where plantation (perkebunan) was reported as the primary livelihood of the majority of villagers in the PODES data and extensive village land area are planted with oil palm plantations and overlap with the oil palm concessions. Oil palm monoculture is a livelihood sector dominated by industrial scale plantations; smallholders mainly operate as part of nucleus estate system, i.e. cooperation between company plantations and smallholders in terms of capital and labour supply (Semedi \& Bakker 2014).

Villages of these four livelihood systems are characterized by different landscapes: high natural forest cover ( $70 \%$ on average) is typical for villages of subsistence livelihoods, moderate natural forest cover for villages of polyculture plantation and freshwater fishing ( $\sim 0 \%$ on average), and highly degraded forest or non-forest for villages of oil palm monoculture ( $20 \%$ on average) (Fig. 1C). Natural forest is defined as a mature forest that has not been completely cleared in the last 30 years. Natural forest cover data every 3 years between 2000 and 2014 were estimated by combining the extent of natural forest (primary and secondary forest according to the Ministry of Environment and Forestry Indonesia) in 2000 derived from Margono et al. (2014) and the forest loss variable in the Global Forest Change (GFC) dataset (Hansen et al. 2013).

Ethnic compositions of the indigenous Dayak and Melayu, and recent migrants (mainly from neighbouring islands of Java, Madura, Bali and Lombok, who arrived mainly as part of government supported transmigration programs since the beginning of the New Order regime in the 1960s), also vary across different livelihood systems (Fig. 1D). The indigenous Dayak communities make up the largest ethnic group in subsistence livelihoods and polyculture plantation villages. In freshwater fishing villages, both the indigenous Dayak and Melayu communities are common. In monoculture plantation villages, the proportion of migrants is highest among all livelihood categories, confirming those reported in other studies (Potter 2012; Sloan et al. 2017). In villages with other livelihood category, the indigenous Dayak and Melayu communities predominate, and migrants are also common.

\subsection{Data}

\subsubsection{Indicators of village economic and socioecological welfare}

We used village boundaries according to the 2014 PODES census as the unit of analysis and 18 indicators of economic and socioecological welfare derived from the PODES data for census years 2000, 2003, 2006, 2008, 2011 and 2014 (Table 1). During data preparation, we encountered three main challenges with the PODES data. The first challenge was related to the inconsistencies in the names of villages reported in the PODES censuses and those described in the village boundary data. Village names in PODES censuses were often reported in local ethnic language, while village names in the spatial data were reported in Indonesian language. The second challenge was related to the shift in village administration from one district (kecamatan) to a neighbouring district, or from one regency (kabupaten) to a neighbouring regency, within two subsequent PODES censuses. To overcome both problems, we first applied an automated matching of regency, district, and village names using $R(R$ Development Core Team 2017), and then for the remaining villages with no match (which typically 
accounts for up to $30 \%$ of the total villages in each province) we conducted search and matching manually. The third challenge was related to the change in village boundaries over time. Every three years between 2000 and 2014, village boundaries across Kalimantan have changed subsequently, as new village administration had been formed, creating division within the older village boundaries (known as pemekaran desa). To allow comparison of villages socioeconomic changes through time, we adjusted each variable by recalculating the original PODES data from the 2000, 2003, 2005, 2008, and 2011 censuses to match the 2014 village boundaries.

Table 1. PODES variables used as indicators for economic and socioecological welfare. Variable $w$ denotes the directionality of the variable response on welfare, where $w$ takes a value of 1 or -1 . If $w=1$, then higher value represents better welfare. If $w=-1$, then lower value represents better welfare. We used these variables in the first analysis (assessing the economic and socioecological merit of villages with different livelihood systems) and third analysis (assessing association between transition towards oil palm monoculture sector and the change in village welfare).

\begin{tabular}{|c|c|c|c|c|}
\hline \multirow{2}{*}{ Aspect } & \multirow{2}{*}{ PODES variable } & \multirow{2}{*}{ Variable response } & \multicolumn{2}{|r|}{ Directionality of variable on welfare } \\
\hline & & & $w$ & Meaning ( $§$ see text for details) \\
\hline \multirow[t]{13}{*}{ Economic } & Living condition & & & \\
\hline & $\begin{array}{l}\text { Proportion of households } \\
\text { with poor housing } \\
\text { conditions * }\end{array}$ & Continuous & -1 & $\begin{array}{l}\text { Welfare is better when fewer } \\
\text { households have poor housing } \\
\text { conditions. }\end{array}$ \\
\hline & $\begin{array}{l}\text { Proportion of households } \\
\text { with electricity }{ }^{*}\end{array}$ & Continuous & 1 & $\begin{array}{l}\text { Welfare is better when more } \\
\text { households have electricity. }\end{array}$ \\
\hline & $\begin{array}{l}\text { Cooking fuel for majority of } \\
\text { households }\end{array}$ & $\begin{array}{l}\text { Ordinal ( } 1=\text { liquefied } \\
\text { petroleum gas (LPG) or } \\
\text { electricity, } 2=\text { kerosene, } \\
3=\text { wood/others) }\end{array}$ & -1 & $\begin{array}{l}\text { Welfare is better when cooking fuel is } \\
\text { at lower category. }\end{array}$ \\
\hline & $\begin{array}{l}\text { Toilet facilities for majority } \\
\text { of households }\end{array}$ & $\begin{array}{l}\text { Ordinal (1=own toilet, } \\
2=\text { joint toilet, } 3=\text { public } \\
\text { toilet, } 4=\text { =non-toilet) }\end{array}$ & -1 & $\begin{array}{l}\text { Welfare is better when toilet facility is } \\
\text { at lower category. }\end{array}$ \\
\hline & $\begin{array}{l}\text { Child malnutrition } \\
\text { prevalence in the last year }+\end{array}$ & Continuous & -1 & $\begin{array}{l}\text { Welfare is better when there are } \\
\text { fewer malnutrition incidents. }\end{array}$ \\
\hline & Infrastructure & & & \\
\hline & $\begin{array}{l}\text { Distance to nearest health } \\
\text { facility }\end{array}$ & Continuous & -1 & $\begin{array}{l}\text { Welfare is better when health } \\
\text { facilities are nearby. }\end{array}$ \\
\hline & $\begin{array}{l}\text { Distance to nearest primary } \\
\text { school }\end{array}$ & Continuous & -1 & $\begin{array}{l}\text { Welfare is better when primary } \\
\text { schools are nearby. }\end{array}$ \\
\hline & $\begin{array}{l}\text { Distance to nearest } \\
\text { secondary school }\end{array}$ & Continuous & -1 & $\begin{array}{l}\text { Welfare is better when secondary } \\
\text { schools are nearby. }\end{array}$ \\
\hline & Income support & & & \\
\hline & $\begin{array}{l}\text { Number of active village } \\
\text { cooperative schemes } \ddagger\end{array}$ & Continuous & 1 & $\begin{array}{l}\text { Welfare is better when active } \\
\text { cooperative schemes or other related } \\
\text { schemes are more prevalent. }\end{array}$ \\
\hline & $\begin{array}{l}\text { Number of credit schemes } \\
\text { for farmers or communities } \\
\ddagger\end{array}$ & Continuous & 1 & $\begin{array}{l}\text { Welfare is better when more credit } \\
\text { schemes are available for farmers or } \\
\text { communities. }\end{array}$ \\
\hline
\end{tabular}

† per 1,000 people, $\ddagger$ per 100 households, * of total households, $* *$ of total agriculture families 
Table 1. Continued.

\begin{tabular}{|c|c|c|c|c|}
\hline \multirow{2}{*}{ Aspect } & \multirow{2}{*}{ PODES variable } & \multirow{2}{*}{ Variable response } & \multicolumn{2}{|r|}{ Directionality of variable on welfare } \\
\hline & & & $w$ & Meaning ( $§$ see text for details) \\
\hline \multirow{10}{*}{$\begin{array}{l}\text { Socio- } \\
\text { ecological }\end{array}$} & Social equity & & & \\
\hline & $\begin{array}{l}\text { Incidence of community } \\
\text { conflicts in the last year } ¥\end{array}$ & Continuous & -1 & $\begin{array}{l}\text { Welfare is better when conflicts are } \\
\text { less prevalent. }\end{array}$ \\
\hline & $\begin{array}{l}\text { Proportion of families with } \\
\text { agricultural wage labourers } \\
* *\end{array}$ & Continuous & -1 & $\begin{array}{l}\text { Welfare is better when families with } \\
\text { agricultural wage labourers are less } \\
\text { prevalent. § }\end{array}$ \\
\hline & $\begin{array}{l}\text { Suicidal rate in the last year } \\
+\end{array}$ & Continuous & -1 & $\begin{array}{l}\text { Welfare is better when there are } \\
\text { fewer suicidal incidents. }\end{array}$ \\
\hline & $\begin{array}{l}\text { Number of small-size } \\
\text { enterprises }(<20 \\
\text { employees }) \ddagger\end{array}$ & Continuous & 1 & $\begin{array}{l}\text { Welfare is better when small } \\
\text { enterprises are more prevalent. } \S\end{array}$ \\
\hline & $\begin{array}{l}\text { Frequency of voluntary } \\
\text { community cleaning and } \\
\text { maintenance (gotong } \\
\text { royong) in the last year }\end{array}$ & Continuous & 1 & $\begin{array}{l}\text { Welfare is better when voluntary } \\
\text { community cleaning and maintenance } \\
\text { (gotong royong) is more frequent. }\end{array}$ \\
\hline & $\begin{array}{l}\text { Pollution and natural } \\
\text { hazard }\end{array}$ & & & \\
\hline & $\begin{array}{l}\text { Water pollution over the } \\
\text { last three years }\end{array}$ & $\begin{array}{l}\text { Ordinal ( } 1=\text { none, } 2=\text { mild, } \\
3=\text { severe) }\end{array}$ & -1 & $\begin{array}{l}\text { Welfare is better when water } \\
\text { pollution is at lower category. }\end{array}$ \\
\hline & $\begin{array}{l}\text { Air pollution over the last } \\
\text { three years }\end{array}$ & $\begin{array}{l}\text { Ordinal ( } 1=\text { none, } 2=\text { mild, } \\
3=\text { severe) }\end{array}$ & -1 & $\begin{array}{l}\text { Welfare is better when air pollution is } \\
\text { at lower category. }\end{array}$ \\
\hline & $\begin{array}{l}\text { Frequency of floods and } \\
\text { landslides in last three } \\
\text { years }\end{array}$ & Continuous & -1 & $\begin{array}{l}\text { Welfare is better when there are } \\
\text { fewer incidents of floods and } \\
\text { landslides. }\end{array}$ \\
\hline
\end{tabular}

† per 1,000 people, $\ddagger$ per 100 households, * of total households, ** of total agriculture families

Economic indicators in the PODES data mainly characterize living condition, infrastructure, and income support, whereas socioecological indicators characterize social equity and natural hazard prevention. Our choice of indicators and directionality of the effects on welfare was informed by existing methodologies used to assess poverty, such as the Multidimensional Poverty Index (Alkire \& Santos 2014), the Sustainable Livelihood Approach (Scoones 1998), and the Nested Spheres of Poverty tool (Gönner et al. 2007). The directionality of indicators described in Table 1 on welfare are all quite straightforward, except for the indicators regarding the proportion of families with agricultural wage labourers and the number of small-size enterprises ( $<20$ employees) (denoted by $\S$ in Table 1$)$. A decrease in the prevalence of agricultural wage labourers in a village was assumed to represent better welfare. PODES defines an agricultural wage labourer as a person who works in the agricultural sector for one or more employers or companies and receives wages on a daily or wholesale basis. Examples of agricultural wage labourer include rice harvesting worker, labourer for preparing paddy fields with hoes, rubber tapping worker, coffee picker, oil palm fruit bunch harvester, and oil palm labourer for fertilization and chemical spraying. Small farmers and agricultural wage labourers remain the poorest segment of society with low purchasing power in developing countries, and in Indonesia this condition has exacerbated despite the country's economic growth (Booth 2012; Van Vliet et al. 2012). An increase in the prevalence of small-size enterprises in a village was assumed to represent better welfare, because it reflected improved distribution of income among communities and the maintenance of diversified local livelihoods (e.g. small-scale industries of non-timber forest products (NTFPs), such as rattans, honey, gaharu, and dammar) (Pambudhi et al. 2004; Dewi et al. 2005), as opposed to the dependency of communities on a single sector income, such as those typically occurring in monoculture plantation villages (Klasen et al. 2016). 
It is worth noting that PODES data represent the overall socioeconomic conditions of communities in a village, and thus do not capture the variation and disparity in socioeconomic indicators among different sub-villages or households. Rather, the data provide a useful way to compare village administrative units over large spatial extents. The data have been used extensively in rural development studies and have proven useful for monitoring the various socioeconomic impacts of landuse policy interventions (e.g. Barron et al. 2009, Jagger \& Rana 2017). In addition, some of the welfare indicators we used in our analysis focused on the prevalence of socioeconomic programmes, such as cooperative schemes, credits, and small businesses, and distance to nearest health facilities and schools. While information about the rates of community participation on socioeconomic activities could provide a better proxy for welfare than merely the prevalence or access to these programs, such data is unfortunately not available in the PODES dataset over the spatial and temporal scale of our study.

\subsubsection{Proxies for village biophysical conditions}

We considered numerous variables as proxies for the biophysical conditions of villages (Table 2). These variables broadly include: (a) socio-political factors, (b) market value, and (c) agriculture productivity. We used provincial boundaries (PROV) and village baseline welfare (WLFR) as proxies for socio-political factors. Decentralization of government functions to provincial levels has been identified as a key driver of land use change and agriculture expansion in Indonesia (Resosudarmo 2004; Moeliono \& Limberg 2012). Economic growth can also vary across different provinces (Suryahadi et al. 2009). The indicator of welfare prior shifting to oil palm monoculture provides a baseline to control for initial conditions that may bias impact estimates.

We used elevation (ELEV), slope (SLOP), proximity to large cities or arterial roads (CITY), distance to rivers $(R I V R)$, population density $(P O P D)$, and distance to industrial oil palm plantations (IOPP) as proxies for market value. Areas closer to roads or rivers, and located at lower elevation and on flat terrain tend to have high anthropogenic pressure because they are more accessible (Kinnaird et al. 2003; Linkie et al. 2004). Agriculture expansion in Kalimantan had been partly attributed to the expansion of oil palm plantation industries (Gaveau et al. 2016b).

We used long-term seasonal rainfall patterns (DRYS and WETS), location on peat soil (PEAT), and monthly mean rainfall during the dry season in a given period (May to September) (DRYT) and the monthly mean rainfall during the wet season in a given period (November to March of the following year) (WETT) as proxies for agriculture productivity. Indeed, long-term rainfall during the dry and wet seasons determines the agro-climatic zones and agricultural productivity in Indonesia (Oldeman \& Frere 1982), and therefore potentially drives land use change and livelihood transition. Soil condition, such as soil type (peat or mineral soil) is also an important factor driving conversion of land to agriculture (Carlson et al. 2013). Extreme climate, such as prolonged dry months and heavy rains, can decrease agricultural productivity (lizumi \& Ramankutty 2015; Oettli et al. 2018) and increase natural disasters such as wildfire and flood (Field et al. 2009; Wells et al. 2017; Santika et al. 2017b). Such extreme events can lead to reduced economic growth and adversely affect community social welfare (Herawati \& Santoso 2011). 
Table 2. Variables used as proxies for village biophysical characteristics. We used these variables in the second analysis (assessing drivers of change in village primary livelihood towards oil palm monoculture) and third analysis (assessing association between transition towards oil palm monoculture sector and the change in village welfare).

\begin{tabular}{|c|c|c|c|}
\hline Variable & Description & Type (Scale) & Data source \\
\hline \multicolumn{4}{|c|}{ SOCIO-POLITICAL } \\
\hline PROV & Provincial boundaries & Categorical & Geospatial Information Agency (BIG 2015) \\
\hline WLFR & $\begin{array}{l}\text { Baseline welfare indicator prior to } \\
\text { transition to oil palm sector (see } \\
\text { Table 1) }\end{array}$ & $\begin{array}{l}\text { Either } \\
\text { continuous or } \\
\text { categorical }\end{array}$ & $\begin{array}{l}\text { Potensi Desa (PODES) data (BPS Indonesia } \\
\text { 2017) }\end{array}$ \\
\hline \multicolumn{4}{|c|}{ MARKET VALUE } \\
\hline ELEV & Elevation & $\begin{array}{l}\text { Continuous } \\
(\log (m))\end{array}$ & $\begin{array}{l}\text { SRTM 90m Digital Elevation Database v4.1 } \\
\text { (Jarvis et al. 2008) }\end{array}$ \\
\hline SLOP & Slope & $\begin{array}{l}\text { Continuous } \\
(\log (\text { degree }))\end{array}$ & $\begin{array}{l}\text { SRTM 90m Digital Elevation Database v4.1 } \\
\text { (Jarvis et al. 2008) }\end{array}$ \\
\hline CITY & $\begin{array}{l}\text { Distance to large cities or arterial } \\
\text { roads }\end{array}$ & $\begin{array}{l}\text { Continuous } \\
(\log (\mathrm{km}))\end{array}$ & Geospatial Information Agency (BIG 2015) \\
\hline$R I V R$ & Distance to rivers & $\begin{array}{l}\text { Continuous } \\
(\log (k m))\end{array}$ & Geospatial Information Agency (BIG 2015) \\
\hline$P O P D$ & Population density & $\begin{array}{l}\text { Continuous } \\
(\log (\text { people }))\end{array}$ & $\begin{array}{l}\text { Potensi Desa (PODES) data (BPS Indonesia } \\
\text { 2017) }\end{array}$ \\
\hline IOPP & $\begin{array}{l}\text { Distance to existing industrial oil } \\
\text { palm plantations }\end{array}$ & $\begin{array}{l}\text { Continuous } \\
(\log (\mathrm{km}))\end{array}$ & MEF (2016); Gaveau et al. (2016a) \\
\hline \multicolumn{4}{|c|}{ AGRICULTURE PRODUCTIVITY } \\
\hline DRYS & $\begin{array}{l}\text { Long-term monthly rainfall during } \\
\text { dry season }\end{array}$ & $\begin{array}{l}\text { Continuous } \\
(\mathrm{mm})\end{array}$ & Worldclim (Hijmans et al. 2004) \\
\hline WETS & $\begin{array}{l}\text { Long-term monthly rainfall during } \\
\text { wet season }\end{array}$ & $\begin{array}{l}\text { Continuous } \\
(\mathrm{mm})\end{array}$ & Worldclim (Hijmans et al. 2004) \\
\hline PEAT & $\begin{array}{l}\text { Majority of soil type (peat versus } \\
\text { mineral soil) }\end{array}$ & Binary & MEF (2016) \\
\hline$D R Y T$ & $\begin{array}{l}\text { Monthly rainfall during the dry } \\
\text { season over time period assessed }\end{array}$ & $\begin{array}{l}\text { Continuous } \\
(\mathrm{mm})\end{array}$ & $\begin{array}{l}\text { TRMM Multi-Satellite Precipitation Analysis } \\
\text { (TMPA) v. } 7 \text { (Huffman et al. 2007) }\end{array}$ \\
\hline WETT & $\begin{array}{l}\text { Monthly rainfall during the wet } \\
\text { season over time period assessed }\end{array}$ & $\begin{array}{l}\text { Continuous } \\
(\mathrm{mm})\end{array}$ & $\begin{array}{l}\text { TRMM Multi-Satellite Precipitation Analysis } \\
\text { (TMPA) v. } 7 \text { (Huffman et al. 2007) }\end{array}$ \\
\hline
\end{tabular}

\subsection{Analyses}

We performed three analysis approaches associated with the three research questions that we aimed to answer. The first analysis provided an overview of the economic and socioecological merit of villages having different livelihood systems (i.e. subsistence livelihoods, freshwater fishing, polyculture plantations, and oil palm monoculture). The second analysis assessed biophysical drivers of change in village primary livelihood (i.e. subsistence livelihoods, freshwater fishing, and polyculture plantations) towards monocultural oil palm cultivation roughly every 5 years between 2000 and 2014. The third analysis assessed the association between the shift in village primary livelihoods (i.e. subsistence livelihoods, freshwater fishing, and polyculture plantations) towards oil palm monocultures and the change in village welfare. A detailed description of each analysis methodology is provided below. 


\subsubsection{Assessing the economic and socioecological merit of villages having different livelihood systems}

For each indicator of welfare described in Table 1, we first multiplied the value by $w$, where $w$ represents the directionality of indicator that defines better welfare. For each indicator of welfare and livelihood category, we calculated the average value across villages with the associated livelihood category. For each indicator and across different livelihood categories, we then normalized the value between 0 and 1 , where ' 0 ' represents the most deprived livelihood system in terms of the given indicator and ' 1 ' represents the most advantaged. For each livelihood category, we then averaged these values across indicators within the economic and socioecological group. This pair-wise index measured the balance between the economic and socioecological merit for each village primary livelihood system.

\subsubsection{Assessing biophysical drivers of change in village primary livelihood towards oil palm monoculture}

We considered biophysical variables described in Table 2 as the potential drivers of change in village primary livelihood towards monocultural oil palm cultivation roughly every 5 years between 2000 and 2014. We first selected villages that had maintained the same primary livelihoods and those that had shifted to oil palm monocultures within 5-6 years, i.e. 2000-2006, 2003-2008, 2006-2011, and 20082014 to match the PODES census years. For villages with the same initial livelihood sector, we fitted a regression tree model implemented in R-package rpart (Therneau et al. 2017) with a binary variable representing whether or not a shift to the oil palm sector had occurred as response, with all variables described in Table 2 as predictors. While the use of other regression models was possible for inferring drivers of village primary livelihood change, we chose the regression tree method mainly due to the flexibility of the model in fitting non-linear relationships between the predictors and the response being measured (Santika \& Hutchinson 2009) and the ease of interpretation. We fitted three regression tree models for subsistence livelihood, freshwater fishing, and polyculture plantation as initial livelihoods. It is worth noting that using this approach we aimed to explore the association between biophysical conditions (agricultural productivity, market value) and livelihood transition towards the oil palm sector, rather than inferring absolute causality.

\subsubsection{Assessing impact of shifting to oil palm monoculture sector on village welfare}

We applied a counterfactual analysis by comparing the change of welfare in villages that had transitioned to oil palm monocultures with the change of welfare in villages that had maintained the same livelihood sector as counterfactual. We investigated two time-lags post livelihood transition: 2-3 years and 9-11 years. The rationale for these time periods is based on the fact that certain crops, such as oil palm, require time to mature and to be harvested (Koh \& Wilcove 2007), and thus some delay is to be expected in the accrual of economic benefits in the villages. For the first time-lag analysis, we selected villages that had maintained the same primary livelihood over 5-6 years or over three consecutive PODES censuses, i.e. 2000-2003-2006, 2003-2006-2008, 2006-2008-2011, and 2008-20112014, and those that had shifted to oil palm monoculture between the first and second survey and then stayed in the oil palm sector until the third survey. For the second time-lag analysis, we selected villages that had maintained the same primary livelihood over 9-11 years or over five consecutive PODES censuses, i.e. 2000-2003-2006-2008-2011 and 2003-2006-2008-2011-2014, and those that had shifted to oil palm monoculture between the first and second surveys and then stayed in the oil palm sector until the fifth survey. The change in village economic and socioecological welfare was quantified using the change in 18 indicators of welfare described in Table 1.

The relative effect of transitioning village livelihood towards oil palm monocultures on the change in each indicator of welfare (Table 1) was estimated following three broad steps. First, we employed a propensity score matching (Deheija \& Wahba 2002) to select control villages that had stayed in the same primary livelihood sector with the same baseline characteristics as villages that had 
shifted to oil palm monoculture. We generated propensity scores by fitting a non-parametric generalized boosted regression model implemented in the R-package gbm (Ridgeway et al. 2015) to a binary variable representing villages with or without livelihood transition to the oil palm sector as a response and all variables described in Table 2 as predictors. We note that variable welfare (WLFR) in Table 2 is associated with the baseline condition of the welfare indicator that we aimed to measure. Thus, the value can either be categorical of continuous.

Second, for each village with livelihood transition to the oil palm sector, we searched for control villages without livelihood transition by matching the propensity scores. We used the nearest neighbour approach implemented in the R-package Matching (Sekhon 2015) with calliper widths 0.25 of the propensity score standard deviations, as this width has previously been shown to be optimal (Austin 2011). We ensured that the key categorical baseline variables (i.e. PROV, WLFR and PEAT) of the control villages exactly matched the characteristics of villages with livelihood transitions to oil palm, and continuous baseline variables were also balanced across villages with and without livelihood transition in the matched dataset. This is to allow fair comparison of villages with different exposure to oil palm.

Third, for each indicator of welfare, we first calculated the change over 2-3 years or 9-11 years, and then multiplied the change by $w$ (Table 1 ). We then divided the value by the maximum of the absolute change of welfare across all villages and time-lags. Thus, we obtained values that ranged roughly between -1 and 1 , where -1 and 1 denotes the largest reduction and improvement in welfare indicator, respectively, and 0 denotes no change in welfare indicator after 2-3 and 9-11 years. We applied this transformation approach mainly to preserve information about the directionality of change in welfare (i.e. improved or declined) over time. We then fitted an ordinary linear regression model to the matched dataset using the transformed values of the change in welfare indicator as a response, a binary variable representing whether or not a transition to oil palm monoculture had occurred, and key variables PROV, WLFR and PEAT (described in Table 2) as predictors. The estimated regression coefficient for the binary variable represented the difference in the pace of improvement or reduction in welfare in villages that had adopted oil palm sector relative to villages that had stayed in the same livelihood sector (and both villages have similar baseline characteristics prior to oil palm development). For example, an indicator of economic welfare - electricity access - is expected to improve across villages in Kalimantan as various developments continue through time, but how much does the extent of improvement occur in villages that had transitioned to oil palm sector to those that had not? Similarly, an indicator of socioecological welfare - water quality -- is expected to deteriorate across villages on the island as various developments disturb the natural environment, but how much does the speed of deterioration occur in villages that had adopted oil palm sector compared to those that had not? For each indicator of welfare, we repeated these procedures for each baseline village livelihood (i.e. subsistence livelihoods, freshwater fishing, and polyculture plantation) and time-lag (i.e. 2-3 year and 911 years).

To obtain the overall effect of a livelihood transition towards monocultural oil palm on economic or socioecological welfare, we averaged the estimated effects across all indicators belonging to each aspect of welfare. Although the estimated effect of livelihood transition was derived using transformed indicators of welfare to allow comparable measures across different indicators, it is worth noting that each indicator of welfare inherently quantifies different things (Table 1). Thus, there are inevitable assumptions of equivalence of impact in one indicator relative to another when averaging in this way. While the averaged indicators provide a pragmatic and informative overview of the impact of oil palm shift on welfare, they should not distract from the nuances in the data provided by individual indicators. 


\section{Results}

\subsection{Economic and socioecological merit of villages having different livelihood systems}

Each major livelihood system differs with respect to baseline economic and socioecological welfare. In villages with predominantly subsistence livelihood communities, the socioecological welfare typically surpassed the economic aspect (Fig. 2). This was depicted from low incidence of conflicts, low rate of agricultural wage labourers, low suicidal rate, high number of small-size enterprises, frequent voluntary community cleaning and maintenance (gotong royong) (Fig. 3E), and lack of water and air pollution and flood incidence (Fig. 3D). However, in subsistence livelihood villages, a large proportion of the communities are under poor living conditions (Fig. 3A) and basic infrastructure is generally lacking (Fig. 3B). In contrast, in villages with oil palm monoculture as the primary sector, the economic welfare typically surpassed the socioecological aspect (Fig. 2). Villages with predominantly polyculture plantation communities generally shared similar welfare to that of the oil palm monoculture villages, but the economic welfare was typically lower than that of the oil palm growing villages while the socioecological welfare was higher (Fig. 2). The welfare characteristics of freshwater fishing villages were quite similar to that of subsistence livelihood villages, except that the economic and socioecological welfare indicators were nearly in equilibrium (Fig. 2).

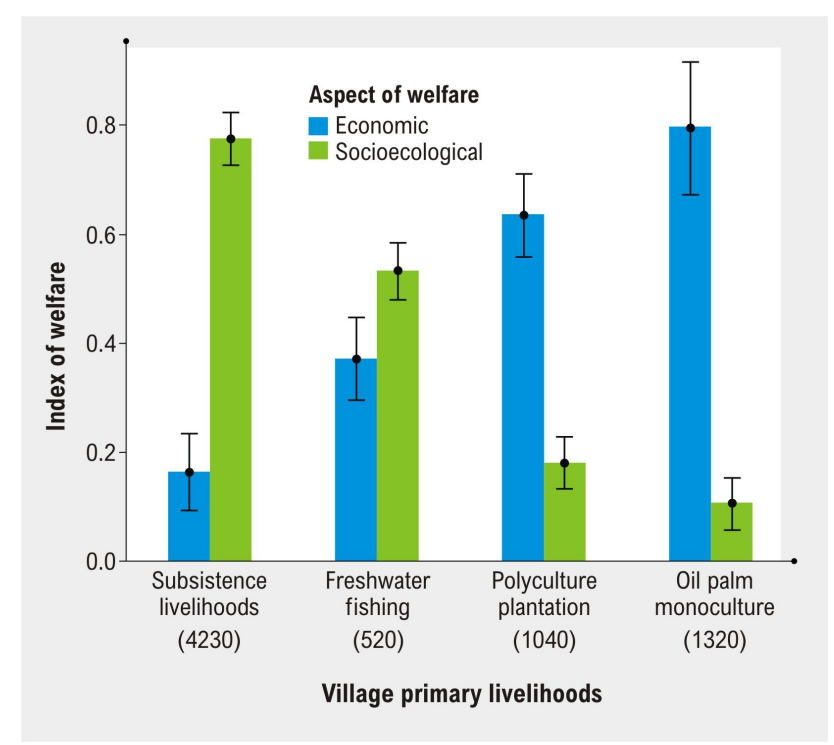

Fig. 2. The balance between economic and socioecological welfare of villages having different livelihood systems in Kalimantan, including subsistence livelihoods, freshwater fishing, polyculture plantation, and oil palm monoculture. Data were averaged across PODES censuses every three years between 2000 and 2014. Number inside the parenthesis below each livelihood category represents the averaged number of villages in the PODES censuses for each livelihood category. Vertical black error bar represents the $95 \%$ confidence interval for the mean. 

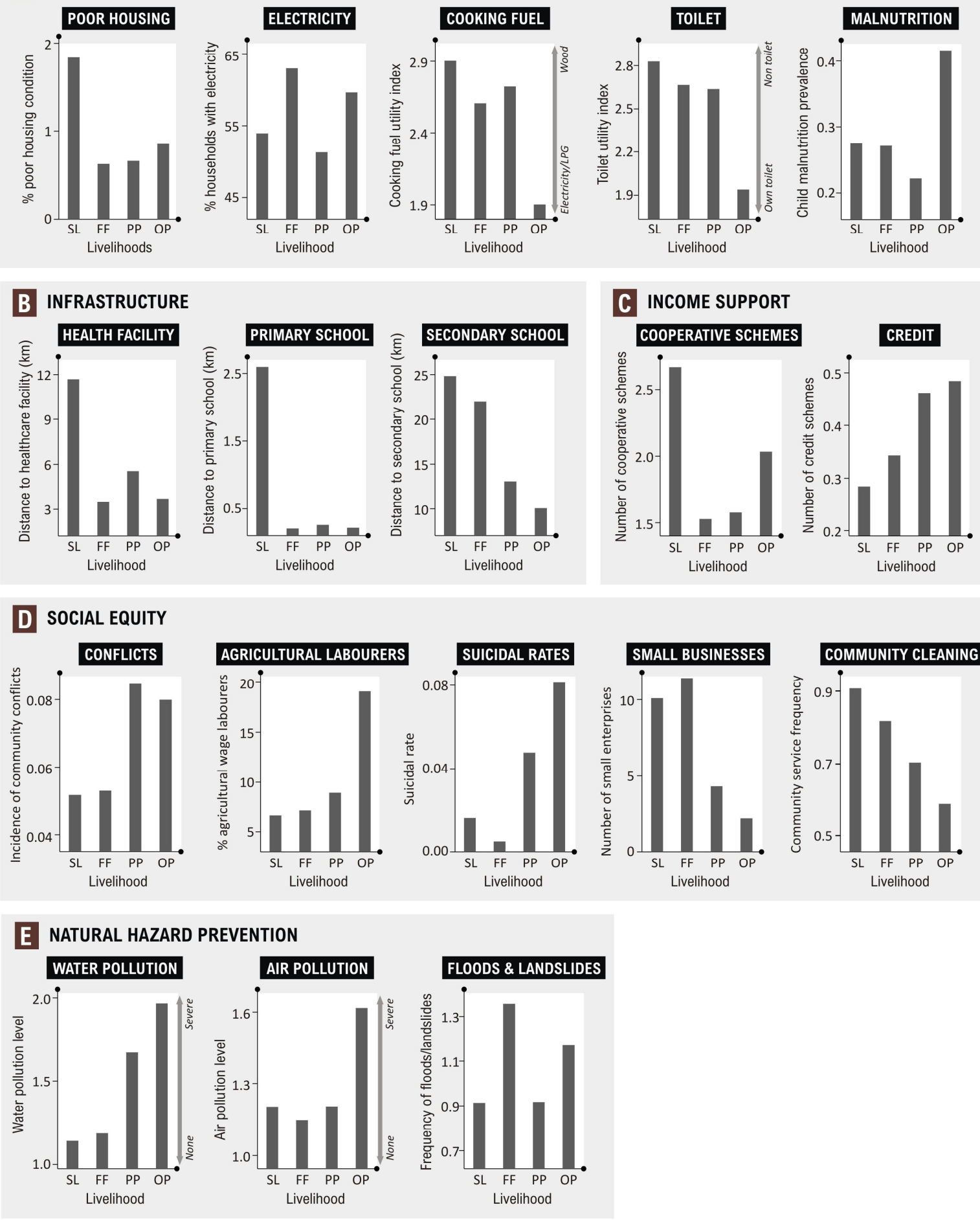

Fig. 3. Economic and socioecological welfare characteristics of villages having different livelihood systems in Kalimantan, including subsistence livelihoods (SL), freshwater fishing (FF), polyculture plantation (PP), and oil palm monoculture (OP). Economic welfare includes: (A) living condition, (B) infrastructure, and (C) income support. Socioecological welfare includes: (D) social equity, and (E) natural hazard prevention. Detail description of each indicator of welfare is given in Table 1. 


\subsection{Biophysical drivers of change in village primary livelihood towards oil palm monoculture}

Roughly every 5 years between 2000 and 2014, about a fifth of villages engaged primarily in subsistence livelihoods, freshwater fishing, or polyculture plantation switched to oil palm monoculture (Fig. 4A). The classification tree model successfully predicts the probability of village primary livelihood transition towards oil palm monoculture, with classification accuracy $89.4 \%, 92.6 \%$, and $86.1 \%$ for baseline village primary sector subsistence livelihood, freshwater fishing, and polyculture plantation, respectively (Fig. 4B). The model estimated the change in village primary sector from subsistence livelihoods to monocultural oil palm; this was associated largely with potential for industrial agriculture (distance to large-scale oil palm plantation $<10 \mathrm{~km}$ and high long-term monthly rainfall during the wet season) and remoteness (population density $<15$ people $/ \mathrm{km}^{2}$ ) (Fig. 4B). Change from freshwater fishing or polyculture plantation to oil palm monoculture was associated largely with recent climatic condition (reduced amount of seasonal rainfall during the dry and wet seasons, respectively) (Fig. 4B).

Remoteness (population density $<50$ people $/ \mathrm{km}^{2}$ ) and proximity to industrial oil palm plantation were also important factors of transition of village primary sector from polyculture plantation to oil palm monoculture (Fig. 4B).

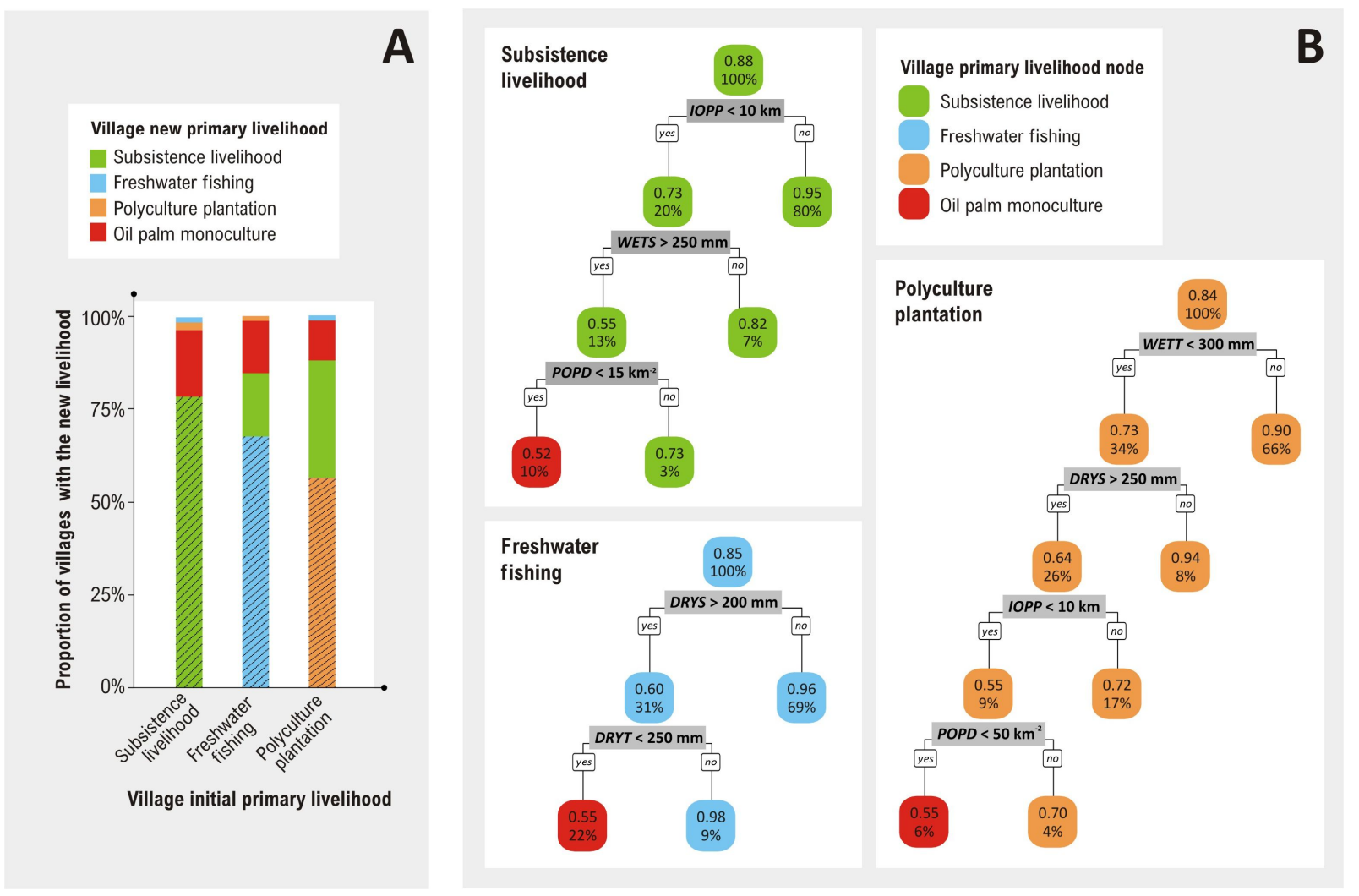

Fig. 4. (A) Proportions of villages with different livelihood transitions from subsistence livelihood, freshwater fishing, and polyculture plantation, to other livelihood sectors, every $\sim 5$ years between 2000 and 2014 across villages in Kalimantan. Proportions of villages that had remained in the same livelihood sector are shown in hatched stripes. (B) Classification trees depicting the drivers of change in village primary sector from subsistence livelihood, freshwater fishing, and polyculture plantation, towards oil palm monoculture. Each node is coloured by the predicted livelihood class and shows the predicted probability of the livelihood class and the percentage of observations. Important biophysical drivers include: market value (human population density POPD as a proxy), agriculture productivity (distance to industrial scale oil palm plantation IOPP, long term mean annual rainfall during the dry and wet seasons, i.e. DRYS and WETS, and mean annual rainfall during the dry and wet seasons 5 years prior to livelihood transition, i.e. DRYT and WETT, as proxies). 


\subsection{Impact of shifting to oil palm monoculture sector on village welfare}

The change in village welfare after moving to monocultural oil palm varied across different village primary livelihoods, reflecting their past exposure to the market economy. A transition from subsistence livelihood (i.e. weak exposure to market system) towards the oil palm sector was associated with a marked increase in economic welfare, but also a marked decrease in socioecological welfare after 2-3 years of transition (Fig. 5A). The benefit from increased economic welfare reduced dramatically after 9-11 years of transition, while a decrease in socioecological welfare became more pronounced. This suggests that the economic benefit of oil palm monocultures only lasted for a short while, since after 911 years villages that chose to retain subsistence livelihoods had been able to reach the same level of economic improvement as those that had adopted oil palm monoculture. The move from freshwater fishing towards oil palm monoculture also had minimal impact on village economic welfare. However, for villages that had chosen to embrace the oil palm sector, the socioecological debt accrued markedly higher than those villages that had chosen to remain in the fishing sector.

On the other hand, a transition from the polyculture plantation sector (i.e. good exposure to market system) to the oil palm sector was associated with increased village economic welfare and the benefit had become optimal after 9-11 of transition (Fig. 5A). Despite a positive impact on the economic welfare, however, village welfare reduced significantly, although the reduction of socioecological welfare had become less pronounced after 9-11 years of transition. It is worth noting that the reduced negative impact of oil palm monoculture on socioecological welfare over the longer time period does not necessarily imply a reduction in the absolute impact. It implies instead that the speed of deterioration of socioecological welfare of villages that had shifted to oil palm monoculture sector had become similar to the speed of deterioration in villages that had stayed in polyculture plantation after longer period.

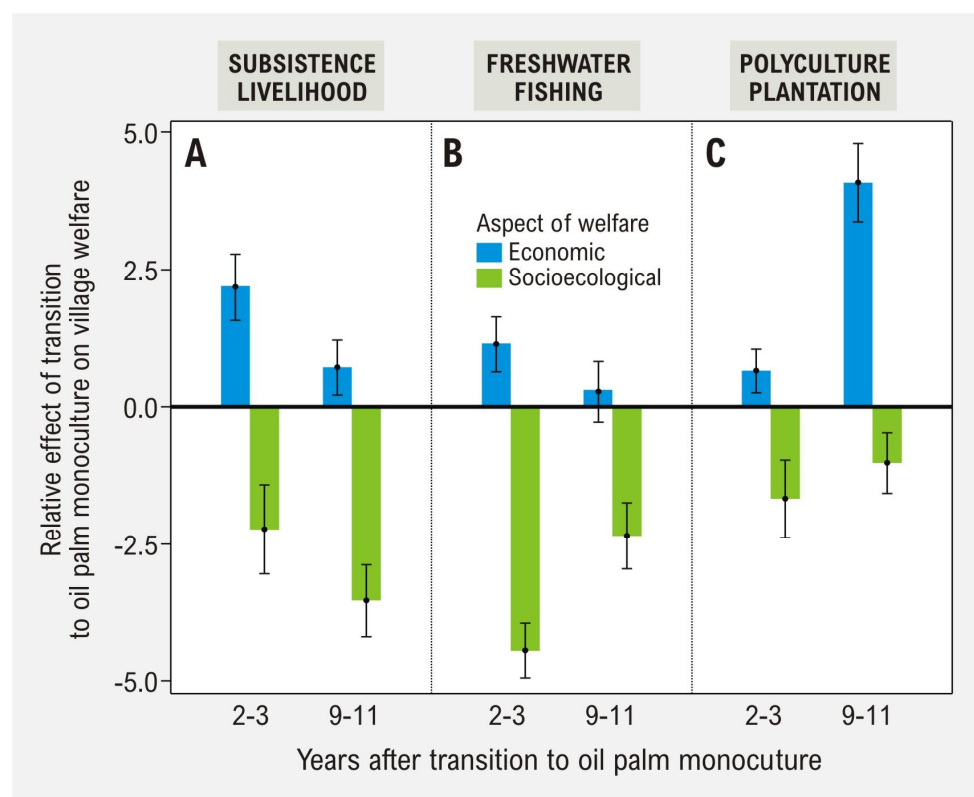

Fig. 5. Relative effect of the change in village primary livelihoods towards oil palm monoculture sector on village welfare, economically and socio-ecologically, after 2-3 years and 9-11 years of transition. Village initial primary sector includes: (A) subsistence livelihood, (B) freshwater fishing, and (C) polyculture plantation. Error bars represent the $95 \%$ confidence interval for the mean. 


\section{Discussion}

Our study presents an integrated landscape analysis towards understanding the nexus between change in landscapes, livelihoods, and rural well-being. We present evidence of the impact of landscape change on shifting livelihoods across villages in Indonesian Borneo between 2000 and 2014, and importantly demonstrate how different circumstances forced communities to pursue different livelihood pathways. We show how the adoption of new livelihood systems could have different implications on rural welfare years later, depending on the baseline economic and socioecological welfare of the community.

\subsection{What drives the change in village primary livelihood towards oil palm monoculture?}

Polyculture plantation villages that experienced reduced seasonal rainfall and were located in remote areas tended to shift away from their current livelihoods towards monocultural oil palm cultivation. This might reflect an adaptation strategy against a changing climate in which the reduction of seasonal rainfall can no longer sustain the current livelihood. For those villages with polyculture plantation livelihoods, such changes to rainfall in a remote area can be particularly challenging, since reduced production can no longer compensate for the already high cost of transporting commodities to the nearest market or city (Bot et al. 2015). For those villages with freshwater fishing livelihoods, the unpredictability of seasonal rainfall can disrupt fish spawning and recruitment, as well as fishers' ability to catch fish (Welcomme \& Halls 2001; Patrick 2016). A drier dry season may require the diversion of more water from water bodies for irrigation for agriculture, compounding the problem of decreased water quality as water levels reduce (Halls \& Welcomme 2004). The result of this is reduced fish capture, and therefore a decline in protein source, barter commodity and income for freshwater fishing villages. For both freshwater fishing and polyculture plantation communities combined, the high agriculture value (fertile soil) of land and the existence of industrial plantation nearby provides ideal opportunity to adopt oil palm monoculture.

Unlike villages with freshwater fishing or polyculture plantation livelihoods where transition to the oil palm sector had been associated with complex interrelation between agriculture pressure and environmental condition, transition from subsistence livelihoods to oil palm monocultures tended to be driven primarily by the expansion of industrial agriculture targeting remote areas with fertile soil, which is likely associated with the ease and low costs of acquiring land (Deininger 2011).

\subsection{What are the impacts of shifting towards oil palm monoculture on village welfare?}

\subsubsection{Impacts vary by baseline village livelihoods prior to oil palm development}

The livelihood transition to oil palm monoculture was associated with a marked increase in economic benefits for villages with polyculture plantation as the primary sector, especially after 9-11 years of transition, the period when oil palm plantations start to be productive (Koh \& Wilcove 2007). Adequate experience in plantation management, and knowledge of and familiarity with the market economy (Fig. 3A-C), are likely key factors for why the economic benefit from oil palm monoculture was optimal and long lasting among polyculture plantation smallholders. Additionally, shifting to oil palm and sending the harvested crop to nearest plantations or mills allowed smallholders in remote areas to save transaction costs (monetary and time) they would have incurred by sending the commodity directly to markets or cities (Laborde Debucquet et al. 2016). The living conditions in communities improved markedly after transitioning to oil palm monoculture, as shown by the continuous increase in proportions of household with electricity and improvement in sanitation and cooking fuel up to 9-11 years of transition (Fig. S2C). Better infrastructure, such as healthcare facilities and schools, was realized after a decade of transition (Fig. S2C). Despite significant gains in economic wealth, the socioecological 
negative implications associated with transition to oil palm were also high, mainly from exacerbated water pollution (Fig. S2C) and decreased community cohesion, i.e. increased influx of agriculture wage labourers from outside the villages (Fig. S2C) (as indicated by increased ethnic diversity (Fig. S3)) and reduced voluntary community cleaning and maintenance (gotong royong) (Fig. S2C). While the local communities could weakly depend on rivers or lakes for drinking water (Fig. 3A), water pollution could have a detrimental affect on the poorest communities within these villages. Water pollution degrades aquatic ecosystems, and many depend on water bodies as sources of protein, regardless of their major livelihood (FAO 2011).

On the other hand, for villages that used to depend on traditional subsistence-based livelihoods (farming, foraging and fishing), a move towards oil palm monoculture appeared to be a serious challenge. This can be related to two things. First, these local communities are shaped from a fundamentally different life system than those based on cash crop agriculture. The dependency on forest and natural resources are the main characteristics of villages with traditional subsistence-based livelihoods (Fig. 2), thus ecosystem deterioration through increasing water and air pollution and floods from the oil palm industry (Fig. S2A-B) could have a negative impact on their existence (Mainusch 2010). Many of these communities also have strong cultural ties with their ancestral livelihoods (Pretty \& Ward 2001), which could make them reluctant to adopt oil palm monoculture. Thus, despite investments and credit opportunities pour into these new oil palm areas at the beginning of oil palm development (Fig. $\mathrm{S} 2 \mathrm{~A}-\mathrm{B}$ ) increasing the economic welfare of the villages overall after transitioning to the oil palm sector relative to the counterfactual (Fig. 5A), the local communities are unlikely to take advantage of the opportunities and do not benefit from such services. In addition, an influx of agricultural wage labourers from outside the village to fill plantation labour quota (Fig. S2A) could overwhelm the existing facilities that had already been lacking (Fig. 3A-B), as reflected by the reduced provision of electricity compared to the counterfactual, and slowing down in the improvement of access to clean sanitation and drinking water after 9-11 years of oil palm plantation development (Fig. S2A). A growing influx of agricultural labourers could further lead to inequitable competition and displacement of local communities and their traditional culture. Thus, for these subsistence-based communities, exacerbation of poverty can be caused not only by isolation from the modern market economy, but also from contact with it (Sunderlin et al. 2005).

The heterogeneous impacts of a transition to monocultural oil palm on welfare in villages having different baseline livelihood systems, particularly between subsistence and non-subsistence based communities, conforms to our literature review on the impacts of oil palm monoculture in developing countries (Table S1). The review found that studies conducted in areas where non-subsistence based communities predominated were more likely to report positive impact of oil palm monoculture on indictors of economic welfare (93\%) than studies conducted in areas where subsistence livelihood communities predominated (20\%). The impact of oil palm monoculture on indicators of socioecological welfare appeared to be negative overall, regardless of livelihood types.

\subsubsection{Impacts of shifting to oil palm monoculture on food security}

In rural areas across Kalimantan, migrant and indigenous communities living in floodplains rely on fishing either for subsistence or to supplement their food needs, although many have shifted to oil palm sector as a major livelihood. If fishing is an important source of food security and it exists regardless of the major livelihoods, then the increase in water pollution, which often follows the switch to oil palm monoculture (Fig. S2), is detrimental not only to those communities that switch livelihoods, but also to all communities within the watershed (Gillett 2009). Climate change could have palpable impact on changing fish distribution and populations, as well as extinction of highly specialized endemic species, and this could further jeopardized the welfare of communities at broader scale (Allison et al. 2009). 
The shift of village primary sector from subsistence livelihood to oil palm monoculture induced a rise in reported cases of malnutrition, both in the early (2-3 years) and late (9-11 years) periods after conversion (Fig. S2A). The change from subsistence to cash crop planting decreased the amount of food cultivation. The relatively slow maturity of the crop means that these households could face a food shortage at least for the first few years in the initial stages of crop establishment. Even when the plantation begins to produce three to four years after planting, the translation from income to improved nutrition is not ensured (Von Braun \& Immink 1994; Palmer \& Di Falco 2012).

\section{Conclusion}

Our study provides the first comprehensive insight on the impact of oil palm production on the village welfare over a large growing area (Kalimantan). We show that the oil palm monoculture sector across Kalimantan brought significant economic benefits to village communities, but this was limited to villages where the majority of communities had prior knowledge of plantation management and past exposure to market economy, such as polyculture plantation villages. For villages where the majority of communities largely depended on traditional subsistence-based livelihoods (including farming, foraging, and fishing), the economic benefit lasted only a few years after transition, while the socioecological capital, in which these village communities had depended and invested most, deteriorated. Refinement of this broad-scale evaluation looking at more nuance impact of oil palm on rural households and whether or not large disparities of impacts exist across different community segments will be required to guide oil palm development policy at subnational level. Nonetheless, our study is crucial in the context of the current oil palm debate, and underscores the need for the governments of producer countries to carefully evaluate oil palm development objectives not only in terms of regional economic gain, but also the future maintenance of socioecological welfare of local communities. Baseline socioeconomic and sociocultural characteristic of rural communities within oil palm development portfolios ought to be considered, as this will critically determine the success of oil palm sector in bringing economic benefits and improving the overall welfare of communities in the long term.

\section{References}

Allison, E.H., Perry, A.L., Badjeck, M.C., Neil Adger, W., Brown, K. et al. (2009) Vulnerability of national economies to the impacts of climate change on fisheries. Fish and Fisheries 10, 173-196.

Alkire, S. \& Santos, M.E. (2014) Measuring acute poverty in the developing world: Robustness and scope of the multidimensional poverty index. World Development 59, 251-274.

Austin, P.C. (2011) Optimal caliper widths for propensity-score matching when estimating differences in means and differences in proportions in observational studies. Pharmaceutical Statistics 10, 150161.

Barron, P., Kaiser, K. \& Pradhan, M. (2009) Understanding variations in local conflict: Evidence and implications from Indonesia. World Development 37, 698-713.

Bebbington, A. (1999) Capitals and capabilities: a framework for analyzing peasant viability, rural livelihoods and poverty. World Development 27, 2021-2044

BIG (Geospatial Information Agency) (2015) Peta Propinsi. Jakarta. Accessed 2 July 2015. Available at: http://www.big.go.id/peta-provinsi.

Booth, A. (2012) The performance of the Indonesian agricultural sector: twelve questions and some tentative answers. In: Land, Livelihood, The Economy and the Environment in Indonesia: Essays in 
Honour of Joan Hardjono (eds. A. Booth, C. Manning \& Thee Kian Wie), pp. 51-84. Jakarta: Yayasan Pustaka Obor Indonesia.

Bot, P., van Donk, D.P., Pennink, B. \& Simatupang, T.M. (2015) Uncertainties in the bidirectional biodiesel supply chain. Journal of Cleaner Production 95, 174-183.

Budiharta, S., Meijaard, E., Wells, J.A., Abram, N.K. \& Wilson, K.A. (2016) Enhancing feasibility: Incorporating a socio-ecological systems framework into restoration planning. Environmental Science \& Policy 64, 83-92.

Bureau of Statistic (BPS) Indonesia (2017) Village Potential Statistics (PODES) 2000, 2003, 2006, 2008, 2011, and 2014. Jakarta, Indonesia.

Buys, P. (2007) At Loggerheads? Agricultural Expansion, Poverty Reduction, and Environment in The Tropical Forests. World Bank Publications.

Carlson, K.M., Curran, L.M., Asner, G.P., Pittman, A.M., Trigg, S.N. et al. (2013) Carbon emissions from forest conversion by Kalimantan oil palm plantations. Nature Climate Change 3, 283.

Carlson, K.M., Heilmayr, R., Gibbs, H.K., Noojipady, P., Burns, D.N. et al. (2018) Effect of oil palm sustainability certification on deforestation and fire in Indonesia. Proceedings of the National Academy of Sciences 115, 121-126.

Dehejia, R.H. \& Wahba, S. (2002) Propensity score-matching methods for nonexperimental causal studies. Review of Economics and Statistics 84, 151-161.

Deininger, K. (2011) Challenges posed by the new wave of farmland investment. The Journal of Peasant Studies 38, 217-247.

Dewi, S., Belcher, B. \& Puntodewo, A. (2005) Village economic opportunity, forest dependence, and rural livelihoods in East Kalimantan, Indonesia. World Development 33, 1419-1434.

Ekadinata, A. \& Vincent, G. (2011) Rubber agroforests in a changing landscape: analysis of land use/cover trajectories in Bungo district, Indonesia. Forests, Trees and Livelihoods 20, 3-14.

Erbaugh, J. \& Agrawal, A. (2017) Clarifying the landscape approach: A Letter to the Editor on "Integrated landscape approaches to managing social and environmental issues in the tropics". Global Change Biology 23, 4453-4454.

Euler, M., Krishna, V., Schwarze, S., Siregar, H. \& Qaim, M. (2017) Oil palm adoption, household welfare, and nutrition among smallholder farmers in Indonesia. World Development 93, 219-235.

Field, R.D., Van Der Werf, G.R., Fanin, T., Fetzer, E.J., Fuller, R. et al. (2016) Indonesian fire activity and smoke pollution in 2015 show persistent nonlinear sensitivity to El Niño-induced drought. Proceedings of the National Academy of Sciences 113, 9204-9209.

Food and Agriculture Organization (FAO) (2011) Fishery and Aquaculture Country Profile Fact Sheets Indonesia. FAO Fisheries and Aquaculture Department. Rome.

Food and Agriculture Organization (FAO) (2015) FAO Statistical Pocketbook: World Food and Agriculture. Food and Agriculture Organization of the United Nations, Rome. Available at: http://www.fao.org/3/a-i4691e.pdf

Gatto, M., Wollni, M. \& Qaim, M. (2015) Oil palm boom and land-use dynamics in Indonesia: the role of policies and socioeconomic factors. Land Use Policy 46, 292-303.

Gaveau, D.L.A., Salim, M. \& Arjasakusuma, S. (2016a) Deforestation and Industrial Plantations Development in Borneo. Center for International Forestry Research (CIFOR) Dataverse, V1.

Gaveau, D.L., Sheil, D., Salim, M.A., Arjasakusuma, S., Ancrenaz, M. et al. (2016b) Rapid conversions and avoided deforestation: examining four decades of industrial plantation expansion in Borneo. Scientific Reports, 6, 32017.

Gillett, R. (2009) Fisheries in the Economies of the Pacific Island Countries and Territories. Asian Development Bank. 
Gönner, C., Haug, M., Cahyat, A., Wollenberg, E., De Jong, W. et al. (2007) Capturing Nested Spheres of Poverty: A Model for Multidimensional Poverty Analysis and Monitoring. Bogor: Center for International Forestry Research (CIFOR).

Halls, A.S. \& Welcomme, R.L. (2004) Dynamics of river fish populations in response to hydrological conditions: a simulation study. River Research and Applications 20, 985-1000.

Hansen, M.C., Potapov, P.V., Moore, R., Hancher, M., Turubanova, S.A.A. et al. (2013) High-resolution global maps of 21st-century forest cover change. Science 342, 850-853.

Herawati, H., \& Santoso, H. (2011) Tropical forest susceptibility to and risk of fire under changing climate: A review of fire nature, policy and institutions in Indonesia. Forest Policy and Economics 13, 227-233.

Hijmans, R.J., Cameron, S.E., Parra, J.L., Jones, P.G. \& Jarvis, A. (2004) The WorldClim Interpolated Global Terrestrial Climate Surfaces Version 1.3. Available at: http://www.worldclim.org.

Huffman, G.J., Bolvin, D.T., Nelkin, E.J., Wolff, D.B., Adler, R.F. et al. (2007) The TRMM multisatellite precipitation analysis (TMPA): Quasi-global, multiyear, combined-sensor precipitation estimates at fine scales. Journal of Hydrometeorology 8, 38-55.

lizumi, T., \& Ramankutty, N. (2015) How do weather and climate influence cropping area and intensity? Global Food Security 4, 46-50.

Jagger, P. \& Rana, P. (2017) Using publicly available social and spatial data to evaluate progress on REDD+ social safeguards in Indonesia. Environmental Science and Policy 76, 59-69.

Jarvis, A., Reuter, H.I., Nelson, A. \& Guevara, E. (2008) Hole-filled SRTM for the Globe Version 4. Available at: http://srtm. csi. cgiar. org.

Kinnaird, M.F., Sanderson, E.W., O'brien, T.G., Wibisono, H.T. \& Woolmer, G. (2003) Deforestation trends in a tropical landscape and implications for endangered large mammals. Conservation Biology 17, 245-257.

Klasen, S., Meyer, K.M., Dislich, C., Euler, M., Faust, H. et al. (2016) Economic and ecological trade-offs of agricultural specialization at different spatial scales. Ecological Economics 122, 111-120.

Koh, L.P. \& Wilcove, D.S. (2007) Cashing in palm oil for conservation. Nature 448, 993-994.

Koplitz, S.N., Mickley, L.J., Marlier, M.E., Buonocore, J.J., Kim, P.S. et al. (2016) Public health impacts of the severe haze in Equatorial Asia in September-October 2015: demonstration of a new framework for informing fire management strategies to reduce downwind smoke exposure. Environmental Research Letters 11, 094023.

Kumagai, T.O., Kanamori, H. \& Yasunari, T. (2013) Deforestation-induced reduction in rainfall. Hydrological Processes 27, 3811-3814.

Krishna, V., Euler, M., Siregar, H. \& Qaim, M. (2017) Differential livelihood impacts of oil palm expansion in Indonesia. Agricultural Economics 48, 639-653.

Laborde Debucquet, D., Majeed, F., Tokgoz, S. \& Torero, M. (2016) Long-term Drivers of Food and Nutrition Security. The International Food Policy Research Institute (IFPRI).

Linkie, M., Smith, R.J. \& Leader-Williams, N. (2004) Mapping and predicting deforestation patterns in the lowlands of Sumatra. Biodiversity and Conservation 13, 1809-1818.

Mainusch, J. (2010) Attitudes to Forestry and Conservation in Indonesia. Forests and SocietyResponding to Global Drivers of Change. IUFRO. Vienna, Austria.

Margono, B.A., Potapov, P.V., Turubanova, S., Stolle, F. \& Hansen, M.C. (2014) Primary forest cover loss in Indonesia over 2000-2012. Nature Climate Change 4, 730-735.

McAlpine, C. A., Johnson, A., Salazar, A., Syktus, J. , Wilson, K. et al. (2018) Forest loss and Borneo's climate. Environmental Research Letters 13, 044009. 
Mertz, O., Wadley, R.L. \& Christensen, A.E. (2005) Local land use strategies in a globalizing world: Subsistence farming, cash crops and income diversification. Agricultural Systems 85, 209-215.

Meijaard, E., Garcia-Ulloa, J., Sheil, D., Carlson, K., Wich, S.A. et al. (2018) Oil Palm and Biodiversity - A Situation Analysis. IUCN Oil Palm Task Force, Gland, Switzerland.

Ministry of Environment and Forestry Indonesia (MEF) (2016) Peta Penutupan Lahan (PPL) 1990-2015. Jakarta, Indonesia.

Moeliono, M. \& Limberg, G. (2012) The Decentralization of Forest Governance: Politics, Economics and the Fight for Control of Forests in Indonesian Borneo. Routledge.

MPOC (2013) Will Palm Oil Survive Climate Change? Malaysian Palm Oil Council. Available at: http://www.mpoc.org.my/Will_palm_oil_survive_climate_change\%5E.aspx

Mukherjee, I. \& Sovacool, B.K. (2014) Palm oil-based biofuels and sustainability in southeast Asia: A review of Indonesia, Malaysia, and Thailand. Renewable and Sustainable Energy Reviews 37, 1-12.

Neiland, A.E. (2008) Tropical River Fisheries Valuation: Background Papers to a Global Synthesis. WorldFish.

Nooteboom, G. \& de Jong Edwin, B.P. (2010) Against 'Green development fantasies': resource degradation and the lack of community resistance in the middle Mahakam wetlands, East Kalimantan, Indonesia. Asian Journal of Social Science 38, 258-278.

Obidzinski, K., Andriani, R., Komarudin, H. \& Andrianto, A. (2012) Environmental and social impacts of oil palm plantations and their implications for biofuel production in Indonesia. Ecology and Society 17, 25.

Obidzinski, K., Dermawan, A. \& Hadianto, A. (2014) Oil palm plantation investments in Indonesia's forest frontiers: limited economic multipliers and uncertain benefits for local communities. Environment, Development and Sustainability 16, 1177-1196.

Oettli, P., Behera, S.K. \& Yamagata, T. (2018) Climate based predictability of oil palm tree yield in Malaysia. Scientific Reports 8, 2271.

Oldeman, L.R. \& Frere, M. (1982) Technical Report on a Study of the Agroclimatology of the Humid Tropics of Southeast Asia. Food \& Agriculture Organizations (FAO), Rome.

Othman, J., Sahani, M., Mahmud, M. \& Ahmad, M.K.S. (2014) Transboundary smoke haze pollution in Malaysia: inpatient health impacts and economic valuation. Environmental Pollution 189, 194-201.

Padoch, C. \& Pinedo-Vasquez, M. (2010) Saving slash-and-burn to save biodiversity. Biotropica 42, 550552.

Palmer, C. \& Di Falco, S. (2012) Biodiversity, poverty, and development. Oxford Review of Economic Policy 28, 48-68.

Pambudhi, F., Belcher, B., Levang, P. \& Dewi, S. (2004) Rattan (Calamus spp.) gardens of Kalimantan: resilience and evolution in a managed non-timber forest product system. In: Forest Products, Livelihoods and Conservation: Case Studies of Non-Timber Forest Product Systems (eds. K. Kuster \& Belcher), pp. 337-354. CIFOR.

Paterson, R.R.M. \& Lima, N. (2018) Climate change affecting oil palm agronomy, and oil palm cultivation increasing climate change, require amelioration. Ecology and Evolution 8, 452-461.

Patrick A.E.S. (2009) Influence of rainfall and water level on inland fisheries production: A review. Archives of Applied Science Research 8, 44-51.

Potter, L. (2012) New transmigration 'paradigm' in Indonesia: Examples from Kalimantan. Asia Pacific Viewpoint 53, 272-287.

Pretty, J. \& Ward, H. (2001) Social capital and the environment. World Development 29, 209-227. 
R Development Core Team (2017) R: A Language and Environment for Statistical Computing. $\mathrm{R}$ Foundation for Statistical Computing, Vienna. Available at: https://www.R-project.org.

Rahu, A.A., Hidayat, K., Ariyadi, M. \& Hakim, L. (2014) Management of Kaleka (traditional gardens) in Dayak community in Kapuas, Central Kalimantan. International Journal of Science and Research 3, 205-210.

Reed, J., Van Vianen, J., Deakin, E.L., Barlow, J. \& Sunderland, T. (2016) Integrated landscape approaches to managing social and environmental issues in the tropics: learning from the past to guide the future. Global Change Biology 22, 2540-2554.

Reed, J., van Vianen, J., Barlow, J. \& Sunderland, T. (2017) Have integrated landscape approaches reconciled societal and environmental issues in the tropics? Land Use Policy 63, 481-492.

Resosudarmo, I.A.P. (2004) Closer to people and trees: will decentralisation work for the people and the forests of Indonesia? The European Journal of Development Research 16, 110-132.

Ridgeway, G., Southworth, M.H., \& R Development Unit (2015) Generalized Boosted Regression Models. R Package Version 2.1.1.

Robinson, G.M. (2018) Globalization of agriculture. Annual Review of Resource Economics 10, 133-160.

Santika, T., Ancrenaz, M., Wilson, K.A., Spehar, S., Abram, N. et al. (2017a) First integrative trend analysis for a great ape species in Borneo. Scientific Reports 7, 4839.

Santika, T. \& Hutchinson, M.F. (2009) The effect of species response form on species distribution model prediction and inference. Ecological Modelling 220, 2365-2379.

Santika, T., Meijaard, E., Budiharta, S., Law, E.A., Kusworo, A. et al. (2017b) Community forest management in Indonesia: Avoided deforestation in the context of anthropogenic and climate complexities. Global Environmental Change 46, 60-71.

Santika, T., Meijaard, E. \& Wilson, K.A. (2015) Designing multifunctional landscapes for forest conservation. Environmental Research Letters 10, 114012.

Sayer, J., Ghazoul, J., Nelson, P. \& Boedhihartono, A.K. (2012) Oil palm expansion transforms tropical landscapes and livelihoods. Global Food Security 1, 114-119.

Scoones, I. (1998) Sustainable Rural Livelihoods: A Framework for Analysis. IDS Working Paper 72. Institute of Development Studies. Brighton, UK.

Scoones, I. (2009) Livelihoods perspectives and rural development. The Journal of Peasant Studies 36, 171-196.

Sekhon, J.S. (2015) Multivariate and Propensity Score Matching with Balance Optimization. R Package Version 4.9-2.

Semedi, P. \& Bakker, L. (2014) Between land grabbing and farmers' benefits: land transfers in West Kalimantan, Indonesia. The Asia Pacific Journal of Anthropology 15, 376-390.

Sloan, S., Campbell, M.J., Alamgir, M., Engert, J., Ishida, F.Y. et al. (2019) Hidden challenges for conservation and development along the Trans-Papuan economic corridor. Environmental Science \& Policy 92, 98-106.

Sloan, S., Locatelli, B., Wooster, M.J. \& Gaveau, D.L. (2017) Fire activity in Borneo driven by industrial land conversion and drought during El Niño periods, 1982-2010. Global Environmental Change 47, 95-109.

Sunderlin, W.D., Angelsen, A., Belcher, B., Burgers, P., Nasi, R. et al. (2005) Livelihoods, forests, and conservation in developing countries: an overview. World Development 33, 1383-1402.

Struebig, M., Kramer-Schadt, S., Wilting, A., Fischer, M., Meijaard, E. et al. (2015) Climate change on Borneo. In: The Future of the Bornean Orangutan: Impacts of Change in Land Cover and Climate (ed. by S. Wich, M. Struebig, J. Refisch, A. Wilting, S. Kramer-Schadt and E. Meijaard), pp. 64. United Nations Environment Programme, Eindhoven. 
Suryahadi, A., Suryadarma, D., \& Sumarto, S. (2009) The effects of location and sectoral components of economic growth on poverty: Evidence from Indonesia. Journal of Development Economics 89, 109117.

Susanti, A. \& Maryudi, A. (2016) Development narratives, notions of forest crisis, and boom of oil palm plantations in Indonesia. Forest Policy and Economics 73, 130-139.

Therneau, T., Atkinson, B., Ripley, B. \& Ripley, M.B. (2017) Package 'rpart'.

Van Vliet, N., Mertz, O., Birch-Thomsen, T. \& Schmook, B. (2013) Is there a continuing rationale for swidden cultivation in the 21st century? Human Ecology 41, 1-5.

Van Vliet, N., Mertz, O., Heinimann, A., Langanke, T., Pascual, U. et al. (2012) Trends, drivers and impacts of changes in swidden cultivation in tropical forest-agriculture frontiers: a global assessment. Global Environmental Change 22, 418-429.

Von Braun, J. \& Immink, M.D.C (1994) Nontraditional vegetable crops and food security among smallholder farmers in Guatemala. In: Agricultural Commercialization, Economic Development, and Nutrition (ed. von Braun, J. \& Kennedy, E.T.) pp. 189-203. Baltimore, MD: Published for the International Food Policy Research Institute (IFPRI) by Johns Hopkins University Press. URL: http://ebrary.ifpri.org/cdm/ref/collection/p15738coll2/id/129377.

Welcomme, R.L. \& Halls, A. (2001) Some considerations of the effects of differences in flood patterns on fish populations. Ecohydrology and Hydrobiology 1, 313-323.

Wells, J.A., Wilson, K.A., Abram, N.K., Nunn, M., Gaveau, D.L.A. et al. (2016) Rising floodwaters: mapping impacts and perceptions of flooding in Borneo. Environmental Research Letters 11, 064016. 
SUPPORTING INFORMATION

Changing landscapes, livelihoods and rural welfare in the context of oil palm development

\section{Supplementary Figures}

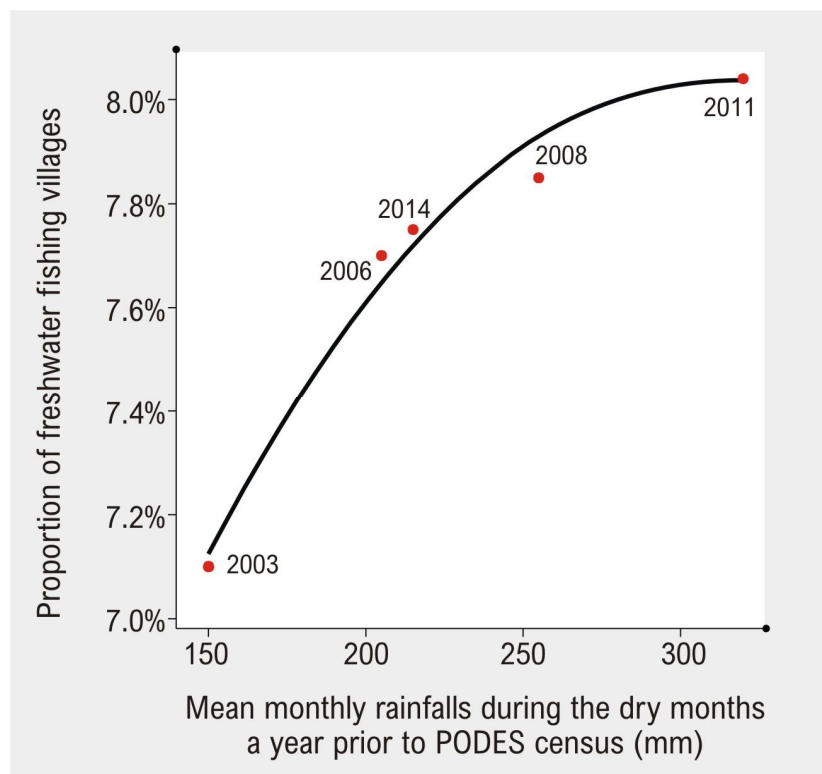

Fig. S1. Relationship between the mean monthly rainfalls during the dry months (May to September) a year prior to PODES census and the proportion on villages reporting freshwater fishing as primary livelihood sector in the PODES data. Label next to each data point represents PODES census year. 

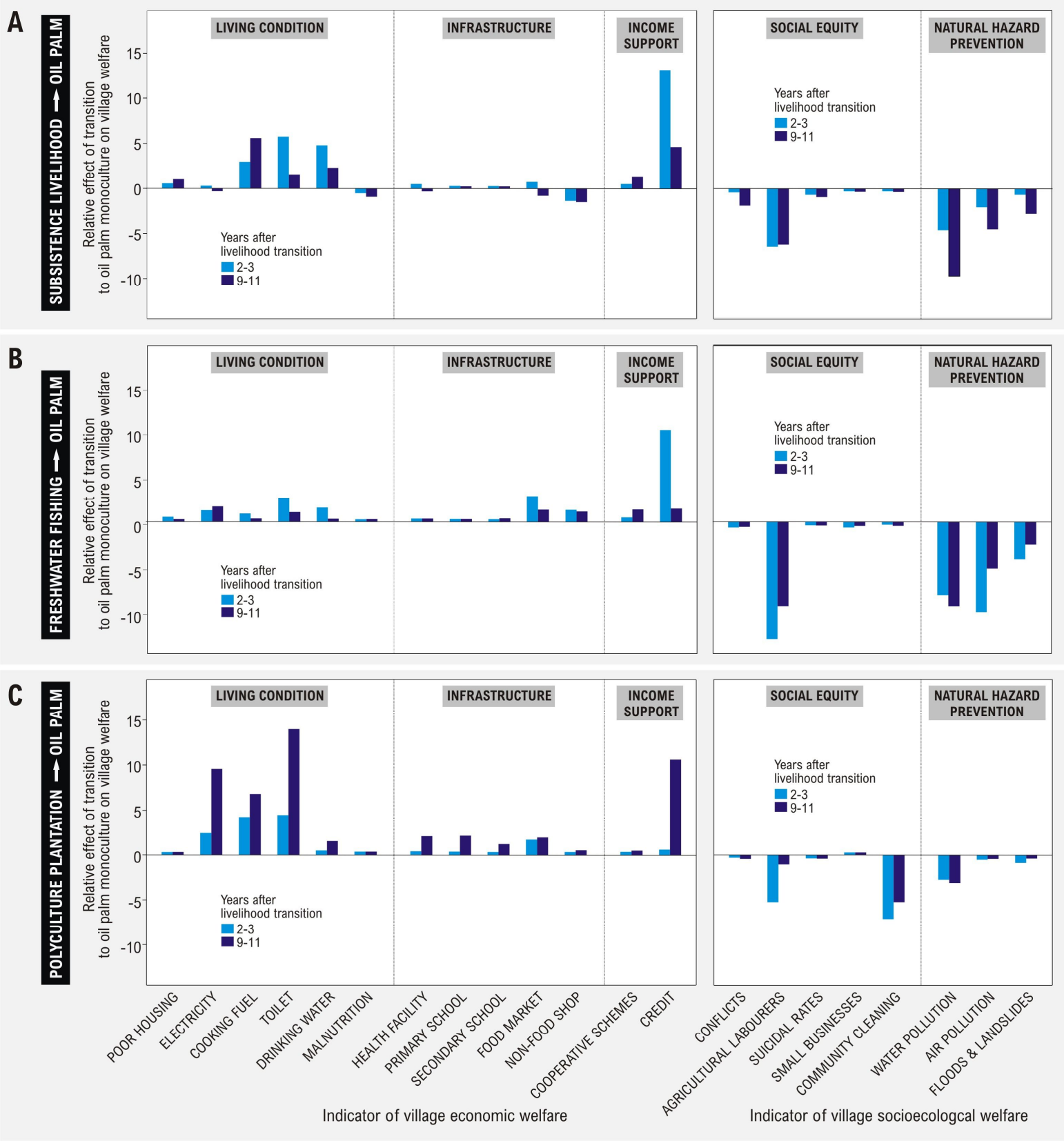

Fig. S2. The association between transition of village primary sector from (A) subsistence livelihood, (B) freshwater fishing, or (C) polyculture plantation, to oil palm monoculture, and the change in economic and socioecological welfare of rural communities, following 2-3 and 9-11 years of transition. Economic welfare includes: living condition, infrastructure, and income support. Ecological welfare includes: social equity and natural hazard prevention. Detail description of each indicator of welfare is given in Table 1. 


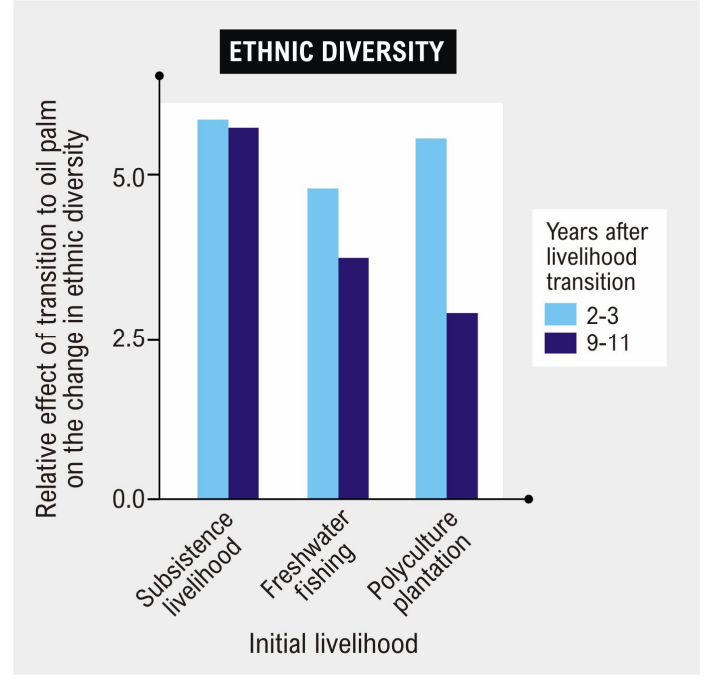

Fig. S3. The associated between transition of village primary sector from subsistence livelihood, freshwater fishing, and polyculture plantation to oil palm monoculture, and the increase in ethnic diversity 2-3 and 9-11 years after transition. 


\section{Supplementary Table}

Table S1. Past evaluations on the impact of industrial-scale oil-palm plantations on the change in welfare in Indonesia, showing a generally positive association between oil palm monoculture and economic welfare, and negative association between oil palm monoculture and socioecological welfare.

\begin{tabular}{|c|c|c|c|c|c|c|}
\hline $\begin{array}{c}\text { Aspect } \\
\text { of welfare }\end{array}$ & $\begin{array}{l}\text { Indicators } \\
\text { of welfare }\end{array}$ & Study area & $\begin{array}{l}\text { Spatial } \\
\text { extent }\end{array}$ & $\begin{array}{l}\text { Subsistence } \\
\text { livelihoods } \\
\text { as baseline } \S\end{array}$ & $\begin{array}{l}\text { Oil palm } \\
\text { impact } \ddagger\end{array}$ & Reference \\
\hline \multirow[t]{18}{*}{ Economic } & \multirow{18}{*}{$\begin{array}{l}\text { Income, } \\
\text { consumption, } \\
\text { employment, and } \\
\text { developments }\end{array}$} & Riau (Sumatra), Indonesia & Local & $\mathrm{N}$ & - & Sinaga (2013) \\
\hline & & Riau (Sumatra), Indonesia & Local & $\mathrm{N}$ & + & Susanti \& Burgers (2011) \\
\hline & & Riau (Sumatra), Indonesia & Local & $\mathrm{N}$ & + & Alwarritzi et al. (2015) \\
\hline & & Jambi (Sumatra), Indonesia & Local & $\mathrm{N}$ & + & Cahyadi \& Waibel (2016) \\
\hline & & Jambi (Sumatra), Indonesia & Local & $N$ & + & Gatto et al. (2017) \\
\hline & & Jambi (Sumatra), Indonesia & Local & $\mathrm{N}$ & + & Krishna et al. (2015) \\
\hline & & Jambi (Sumatra), Indonesia & Local & $\mathrm{N}$ & + & Euler et al. (2017) \\
\hline & & Bungo (Sumatra), Indonesia & Local & $\mathrm{N}$ & + & Feintrenie et al. (2010) \\
\hline & & Bungo (Sumatra), Indonesia & Local & $\mathrm{N}$ & + & Rist et al. (2010) \\
\hline & & Sumatra, Kalimantan \& Sulawesi, Indonesia & Regional & $\mathrm{N}$ & + & Budidarsono et al. (2012) \\
\hline & & Sanggau (Kalimantan), Indonesia & Local & $\mathrm{N}$ & + & Julia \& White (2012) \\
\hline & & Kutai Kertanegara (Kalimantan), Indonesia & Local & $\mathrm{N}$ & + & Dharmawan et al. (2016) \\
\hline & & West Kalimantan, Indonesia & Local & $\mathrm{Y}$ & - & Sirait (2009) \\
\hline & & Manokwari (West Papua) & Local & Y & + & Obidzinski et al. (2012) \\
\hline & & Kubu Raya (Kalimantan) & Local & Y & - & Obidzinski et al. (2012) \\
\hline & & Boven Digoel (Papua) & Local & $\mathrm{Y}$ & - & Obidzinski et al. (2012) \\
\hline & & Summary & & $\mathrm{N}=12$ & $\mathrm{~N}+=11(92 \%)$ & \\
\hline & & & & $Y=4$ & $\mathrm{Y}+=1(25 \%)$ & \\
\hline
\end{tabular}

$¥$ Oil palm impact on welfare indicators: Positive (+), Negative $(-)$

$\S$ Whether or not the majority of communities within study area have relied on subsistence livelihoods at the beginning of oil palm development: Yes ( $\mathrm{Y}$ ), No ( $\mathrm{N}$ ) 
Table S1. (Continued)

\begin{tabular}{|c|c|c|c|c|c|c|}
\hline $\begin{array}{c}\text { Aspect } \\
\text { of welfare }\end{array}$ & $\begin{array}{l}\text { Indicators } \\
\text { of welfare }\end{array}$ & Study area & $\begin{array}{l}\text { Spatial } \\
\text { extent }\end{array}$ & $\begin{array}{c}\text { Subsistence } \\
\text { livelihoods } \\
\text { as baseline } \S \\
\end{array}$ & $\begin{array}{l}\text { Oil palm } \\
\text { impact } \ddagger\end{array}$ & Reference \\
\hline \multirow[t]{18}{*}{ Social } & \multirow{16}{*}{$\begin{array}{l}\text { Security, social or } \\
\text { gender equities }\end{array}$} & Bungo (Sumatra), Indonesia & Local & $\mathrm{N}$ & - & Rist et al. (2010) \\
\hline & & Riau (Sumatra), Indonesia & Local & $N$ & - & Sinaga (2013) \\
\hline & & Jambi (Sumatra), Indonesia & Local & $\mathrm{N}$ & - & Euler et al. (2017) \\
\hline & & Jambi (Sumatra), Indonesia & Local & $\mathrm{N}$ & - & Manik et al. (2013) \\
\hline & & Sanggau (Kalimantan), Indonesia & Local & $\mathrm{N}$ & - & Julia \& White (2012) \\
\hline & & Sanggau (Kalimantan), Indonesia & Local & $\mathrm{N}$ & - & $\mathrm{Li}(2015)$ \\
\hline & & Berau (Kalimantan), Indonesia & Local & $\mathrm{N}$ & - & Elmhirst et al. (2015) \\
\hline & & West Kalimantan, Indonesia & Local & $\mathrm{N}$ & - & de $\operatorname{Vos}(2016)$ \\
\hline & & Kalimantan, Indonesia & Regional & $\mathrm{N}$ & - & Abram et al. (2017) \\
\hline & & West Kalimantan, Indonesia & Local & Y & - & Sirait (2009) \\
\hline & & East Kutai (Kalimantan), Indonesia & Local & Y & - & Elmhirst et al. (2015) \\
\hline & & Kalimantan, Indonesia & Regional & Y & - & Abram et al. (2017) \\
\hline & & Manokwari (West Papua), Indonesia & Local & Y & - & Obidzinski et al. (2012) \\
\hline & & Kubu Raya (Kalimantan), Indonesia & Local & Y & - & Obidzinski et al. (2012) \\
\hline & & Boven Digoel (Papua) & Local & Y & - & Obidzinski et al. (2012) \\
\hline & & Papua, Indonesia & Local & Y & - & Obidzinski et al. (2014) \\
\hline & & \multirow[t]{2}{*}{ Summary } & & $\mathrm{N}=9$ & $\mathrm{~N}+=0(0 \%)$ & \\
\hline & & & & $Y=7$ & $\mathrm{Y}+=0(0 \%)$ & \\
\hline
\end{tabular}

¥ Oil palm impact on welfare indicators: Positive (+), Negative (-)

$\S$ Whether or not the majority of communities within study area have relied on subsistence livelihoods at the beginning of oil palm development: Yes ( $\mathrm{Y}$ ), No (N) 
Table S1. (Continued)

\begin{tabular}{|c|c|c|c|c|c|c|}
\hline $\begin{array}{c}\text { Aspect } \\
\text { of welfare }\end{array}$ & $\begin{array}{l}\text { Indicator } \\
\text { of welfare }\end{array}$ & Study area & $\begin{array}{l}\text { Spatial } \\
\text { extent }\end{array}$ & $\begin{array}{c}\text { Subsistence } \\
\text { livelihoods } \\
\text { as baseline } \S \\
\end{array}$ & $\begin{array}{l}\text { Oil palm } \\
\text { impact } \ddagger\end{array}$ & Reference \\
\hline \multirow[t]{8}{*}{ Ecological } & \multirow{6}{*}{$\begin{array}{l}\text { Water, air or soil } \\
\text { quality }\end{array}$} & Riau (Sumatra), Indonesia & Local & $N$ & - & Comte et al. (2015) \\
\hline & & Jambi (Sumatra), Indonesia & Local & $\mathrm{N}$ & - & Merten et al. (2016) \\
\hline & & Kutai Kertanegara (Kalimantan), Indonesia & Local & $\mathrm{N}$ & - & Dharmawan et al. (2016) \\
\hline & & Manokwari (West Papua), Indonesia & Local & Y & - & Obidzinski et al. (2012) \\
\hline & & Kubu Raya (Kalimantan), Indonesia & Local & Y & - & Obidzinski et al. (2012) \\
\hline & & Boven Digoel (Papua) & Local & Y & - & Obidzinski et al. (2012) \\
\hline & & \multirow{2}{*}{ Summary } & & $N=3$ & $\mathrm{~N}+=0(0 \%)$ & \\
\hline & & & & $Y=3$ & $\mathrm{Y}+=0(0 \%)$ & \\
\hline
\end{tabular}

$\ddagger$ Oil palm impact on welfare indicators: Positive (+), Negative (-)

$\S$ Whether or not the majority of communities within study area have relied on subsistence livelihoods at the beginning of oil palm development: Yes ( $\mathrm{Y}$ ), No ( $\mathrm{N}$ ) 


\section{References Table S1}

Abram, N.K., Meijaard, E., Wilson, K.A., Davis, J.T., Wells, J.A. et al. (2017) Oil palm-community conflict mapping in Indonesia: A case for better community liaison in planning for development initiatives. Applied Geography 78, 33-44.

Alwarritzi, W., Nanseki, T. \& Chomei, Y. (2015) Impact of oil palm expansion on farmers' crop income and poverty reduction in Indonesia: An application of propensity score matching. The Journal of Agricultural Science 8, 119.

Budidarsono, S., Dewi, S., Sofiyuddin, M. \& Rahmanulloh, A. (2012) Socioeconomic impact assessment of palm oil production. Technical Brief No. 27. World Agroforestry Centre (ICRAF).

Cahyadi, E.R. \& Waibel, H. (2016) Contract farming and vulnerability to poverty among oil palm smallholders in Indonesia. Journal of Development Studies 52, 681-695.

Comte, I., Colin, F., Grünberger, O., Whalen, J.K., Widodo, R.H. et al. (2015) Watershed-scale assessment of oil palm cultivation impact on water quality and nutrient fluxes: a case study in Sumatra (Indonesia). Environmental Science and Pollution Research 22, 7676-7695.

de Vos, R.E. (2016) Multi-functional lands facing oil palm monocultures: A case study of a land conflict in West Kalimantan, Indonesia. Austrian Journal of South-East Asian Studies 9, 11-32.

Dharmawan, A.H., Mardiyaningsih, D.I. \& Yulian, B.E. (2016) Expansion of oil palm plantation and changes in social, economic and rural ecology: A case study in Kutai Kartanegara. Project Working Paper Series OPAL No. 01/2016.

Elmhirst, R., Siscawati, M. \& Sijapati Basnett, B. (2015) Navigating investment and dispossession: gendered impacts of the oil palm 'land rush' in East Kalimantan, Indonesia. In: Land Grabbing, Conflict and Agrarian-Environmental Transformations: Perspectives from East and Southeast Asia. Chiang Mai, Thailand.

Euler, M., Krishna, V., Schwarze, S., Siregar, H. \& Qaim, M. (2017) Oil palm adoption, household welfare, and nutrition among smallholder farmers in Indonesia. World Development 93, 219-235.

Feintrenie, L., Chong, W.K. \& Levang, P. (2010) Why do farmers prefer oil palm? Lessons learnt from Bungo district, Indonesia. Small Scale Forestry 9, 379-396.

Gatto, M., Wollni, M., Asnawi, R. \& Qaim, M. (2017) Oil palm boom, contract farming, and rural economic development: Village-level evidence from Indonesia. World Development 95, 127-140.

Julia \& White, B. (2012) Gendered experiences of dispossession: oil palm expansion in a Dayak Hibun community in West Kalimantan. Journal of Peasant Studies 39, 995-1016.

Krishna, V.V., Euler, M., Siregar, H., Fathoni, Z. \& Qaim, M. (2015) Farmer heterogeneity and differential livelihood impacts of oil palm expansion among smallholders in Sumatra, Indonesia. EFForTS Discussion Paper Series No. 13.

Li, T.M. (2015) Social Impacts of Oil Palm in Indonesia: A Gendered Perspective from West Kalimantan. Center for International Forestry Research (CIFOR) Vol. 124.

Manik, Y., Leahy, J. \& Halog, A. (2013) Social life cycle assessment of palm oil biodiesel: a case study in Jambi Province of Indonesia. The International Journal of Life Cycle Assessment 18, 1386-1392.

Merten, J., Röll, A., Guillaume, T., Meijide, A., Tarigan, S. et al. (2016) Water scarcity and oil palm expansion: social views and environmental processes. Ecology and Society 21, 5.

Obidzinski, K., Andriani, R., Komarudin, H. \& Andrianto, A. (2012) Environmental and social impacts of oil palm plantations and their implications for biofuel production in Indonesia. Ecology and Society 17, 25. 
Obidzinski, K., Dermawan, A. \& Hadianto, A. (2014) Oil palm plantation investments in Indonesia's forest frontiers: limited economic multipliers and uncertain benefits for local communities. Environment, Development and Sustainability 16, 1177-1196.

Rist, L., Feintrenie, L. \& Levang, P. (2010) The livelihood impacts of oil palm: smallholders in Indonesia. Biodiversity Conservation 19, 1009-1024.

Sinaga, H. (2013) Employment and income of workers on Indonesian oil palm plantations: food crisis at the micro level. Journal of the Science of Food and Agriculture 1, 64-78.

Sirait, M. (2009) Indigenous peoples and oil palm plantation expansion in West Kalimantan, Indonesia. The Hague: Cordaid Memisa.

Susanti, A. \& Burgers, P.P.M. (2011) Oil palm expansion in Riau province, Indonesia: Serving people, planet, profit? The European Report on Development. 